\title{
MONITORAMENTO DA FERTILIDADE DO SOLO, NUTRIÇÃO MINERAL E CRESCIMENTO DE UM POVOAMENTO DE Eucalyptus grandis FERTILIZADO COM BIOSSÓLIDO
}

\section{Gilberto Neves da Rocha}

Biólogo

Orientador: Prof. Dr. JOSÉ LEONARDO DE MORAES GONÇALVES

Dissertação apresentada à Escola Superior de Agricultura "Luiz de Queiroz", Universidade de São Paulo, para obtenção do título de Mestre em Recursos Florestais, com opção em Manejo de Florestas de Produção.

\author{
PIRACICABA \\ Estado de São Paulo - Brasil \\ Setembro - 2002
}




\section{Dados Internacionais de Catalogação na Publicação (CIP) DIVISÃO DE BIBLIOTECA E DOCUMENTAÇÃO - ESALQ/USP}

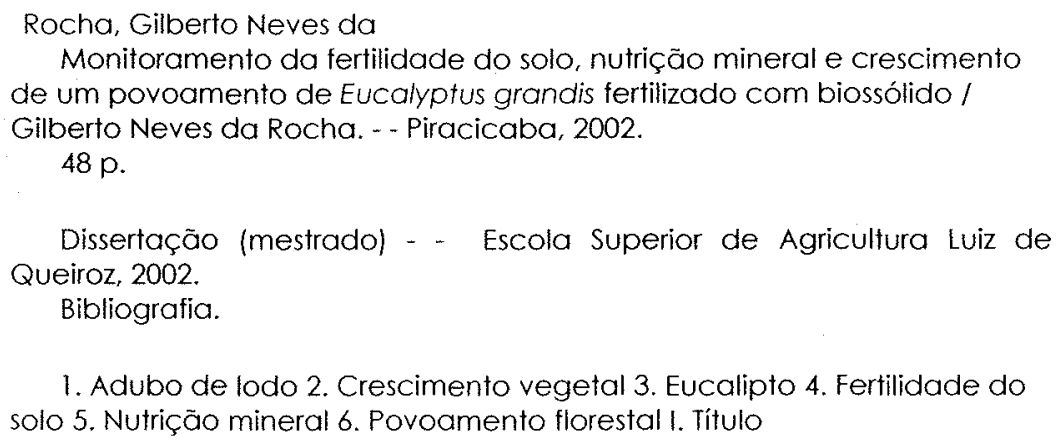

1. Adubo de lodo 2. Crescimento vegetal 3. Eucalipto 4. Fertilidade do solo 5. Nutrição mineral 6. Povoamento florestal I. Título

CDD 634.9734

\section{"Permitida a cópia total ou parcial deste documento, desde que citada a fonte $-\mathbf{O}$ autor"}


Dedico, não apenas este trabalho, mas toda a agradável vivência deste periodo, a meus pais (Aguinaldo e Cecília), a meus irmãos, cunhado e sobrinhas e à minha querida artista do viver,Patrícia, cuja original sabedoria que insiste em achar que não possui proporcionou-me a felicidade de um mundo novo que acreditava não existir.

"Vivendo se aprende, mas o que se aprende, mais, é só a fazer outras maiores perguntas."

"Porque aprender-a-viver é que é o viver, mesmo." (João Guimarães Rosa, Grande Sertão: Veredas) 


\section{AGRADECIMENTOS}

Queria começar agradecendo aos heróis da resistência ainda presentes em meu couro cabeludo, diga-se de passagem, couro quase semi-cabeludo, por não terem deserdado, como muitos o fizeram, de suas funções nos momentos mais dificeis deste trabalho, e à Nossa Senhora dos Sucos Verdes e Folhas de Bálsamo, pelo bom trabalho de distração daquela famosa gastrite que vem anexa a muitos dos trabalhos de pós-graduação;

Agradeço às pessoas que me incentivaram a buscar algo mais do que o já conhecido e a desconfiar sempre do que se tem como verdade maior;

Agradeço ao Prof. José Leonardo, pela confiança de que tudo daria certo, apesar de tantas incertezas no caminho; agradeço aos colegas de projeto e aos colegas de curso;

agradeço a todos da equipe de apoio - secretarias, viveiro de mudas e serviços gerais do Depto. de Ciências Florestais, além do IPEF (informática e biblioteca) -, cuja paciência e dedicação nos foram de grande valia nos momentos de angustia;

agradeço a toda equipe da Estação Experimental de Itatinga, pela ajuda, seriedade e companheirismo durante minha estada para as coletas de dados;

agradeço à turma do Laboratório de Ecologia Aplicada (LEA), pelo profissionalismo e preocupação de bem atender às necessidades científicas;

agradeço aos funcionários da ESALQ/USP, pela organização para que tudo,enfim, acontecesse;

agradeço ao Prof. Fábio Poggianni, à Profa. Maria Emília Mattiazzo-Prezzoto e ao Dr. Paulo César Teixeira, pelas críticas e sugestões apresentadas;

agradeço às colegas de orientação, Thaís e Fabiane (Neon), pela agradável e solidária companhia;

agradeço às novas amizades nascidas em Piracicaba e que estarão presentes sempre, independentes da distância em que nos encontremos;

agradeço aos meus irmãos Júnior, Beatriz e Eliane, ao cunhado Sebastião e às pequenas Esther e Isadora, simplesmente porque, parte do que sou hoje, vem do que vivemos ontem e sempre vou querer vestir meu futuro com a presença de vocês;

agradeço a meus pais, Aguinaldo e Cecília, pela doação de suas vidas à felicidade dos filhos, proporcionando, muito além de cada caminho por nós escolhido, os vários caminhos para que pudéssemos, enfim, ter o poder da escolha;

agradeço ao Felipe, pela confiança, diversão e amizade a mim destinados, e pelo carinho com que fui recebido;

e agradeço à sorte do encontro da real companhia, pois foi no início desta jornada que encontrei a parte que faltava para vôos mais altos e fascinantes de minha alma e que tornara-se primordial em tantos momentos decisivos: à minha querida Patrícia, ofereço cada página desta dissertação. 


\section{S U MÁRIO}

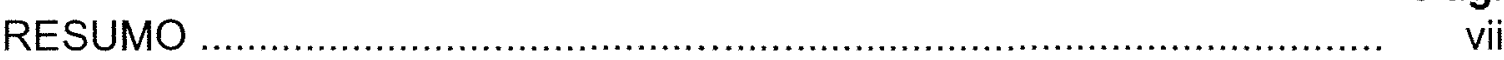

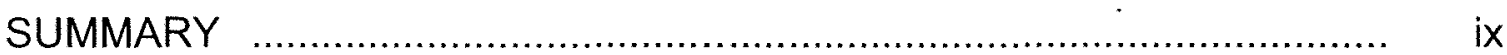

1 INTRODUÇÃO

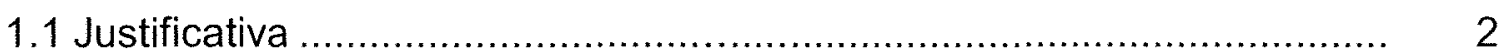

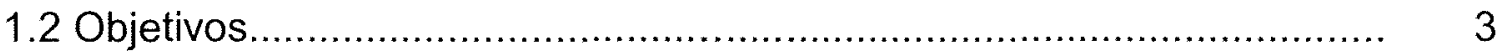

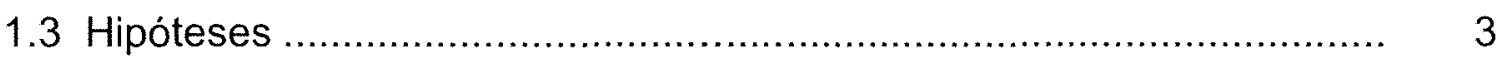

2 REVISÃO DE LITERATURA ....................................................... 4

2.1 Definição de biossólido ....................................................................... 4

2.2 Biossólido como otimizador da fertilidade do solo ................................ 5

2.3 Potencial do uso biossólido na atividade florestal ................................ 6

3 MATERIAL E MÉTODOS …......................................................... 9

3.1 Caracterização da área experimental ................................................. 9

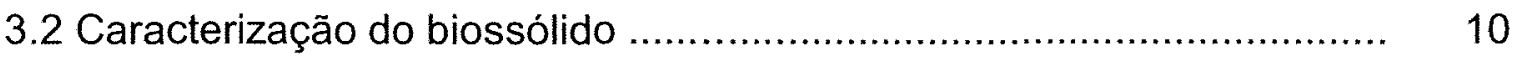

3.3 Tratamentos e delineamento experimental ......................................... 11

3.4 Medição das condições climáticas ....................................................... 13

3.5 Monitoramento da fertilidade do solo ................................................. 13

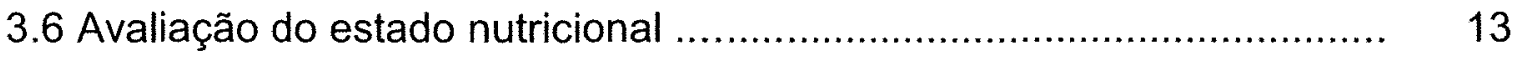

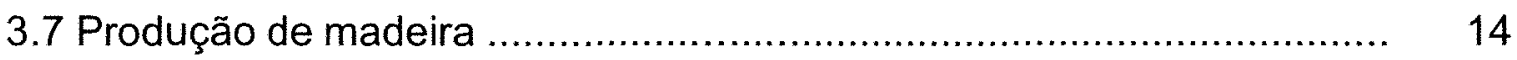

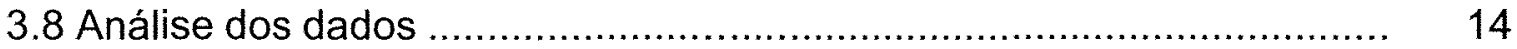

4 RESULTADOS E DISCUSSÃO ……………………………............... 15

4.1 Monitoramento das condições climáticas ............................................. 15

4.2 Fertilidade do solo ................................................................... 15

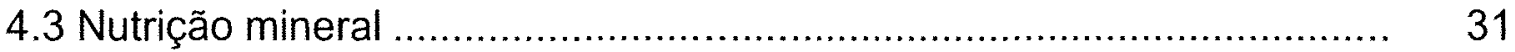




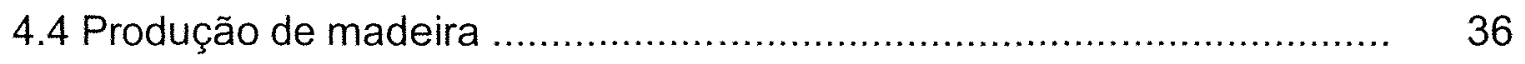

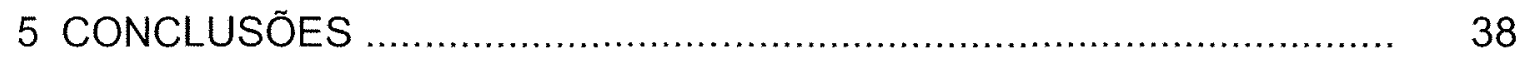

REFERÊNCIAS BIBLIOGRÁFICAS ........................................... 39 


\title{
MONITORAMENTO DA FERTILIDADE DO SOLO, NUTRIÇÃO MINERAL E CRESCIMENTO DE UM POVOAMENTO DE Eucalyptus grandis FERTILIZADO COM BIOSSÓLIDO
}

\author{
Autor: GILBERTO NEVES DA ROCHA \\ Orientador: Prof. Dr. JOSÉ LEONARDO DE M. GONÇALVES
}

\section{RESUMO}

A fertilidade do solo, o estado nutricional e o crescimento de um povoamento de Eucalyptus grandis fertilizado com biossólido foram avaliados, em um experimento na Estação Experimental de Itatinga, SP, da ESALQ/USP. O delineamento utilizado foi de blocos casualizados, com quatro blocos e nove tratamentos, dos quais sete receberam biossólido. Os tratamentos avaliados foram: 1) Testemunha; 2) Adubação mineral; 3) $5 \mathrm{t} \mathrm{ha}^{-1}+\mathrm{K}$; 4) $10 \mathrm{t} \mathrm{ha}^{-1}+\mathrm{K}$; 5) $10 \mathrm{t} \mathrm{ha}^{-1}$; 6) $10 \mathrm{tha}+\mathrm{K}+\mathrm{P}$; 7) $15 \mathrm{t} \mathrm{ha} \mathrm{h}^{-1}+\mathrm{K}$; 8) $20 \mathrm{tha}^{-1}+\mathrm{K}$; e 9) $40 \mathrm{t} \mathrm{ha}^{-1} \mathrm{de}$ biossólido $+K$. Foram analisadas amostras de solo (camadas 0-5, 5-10 e 10-20 $\mathrm{cm}$ ), quanto ao $\mathrm{pH}$ e aos teores de macronutrientes, e de folhas, quanto aos teores de macro e micronutrientes, exceto o boro. $O$ crescimento das árvores foi avaliado pela biomassa de madeira. Até os 32 meses da aplicação do biossólido, 36 meses de idade do povoamento, constatou-se: elevação dos teores de carbono orgânico e pH, este atingindo valores de 5,8 e 6,2, nas doses de 20 e $40 \mathrm{t} \mathrm{ha}^{-1}+\mathrm{K}$, respectivamente, na profundidade de $0-5 \mathrm{~cm}$; elevada disponibilização de $\mathrm{P}$ e $\mathrm{Ca}$ nas três profundidades, associadas às doses de biossólido aplicadas, principalmente nas doses de 20 e $40 \mathrm{tha}^{-1}+\mathrm{K}$, as quais foram superiores à adubação mineral; redução dos teores de $S$ e $K$ nos 
primeiros treze meses, tendo como possíveis causas a lixiviação e absorção pelas árvores, e aumento destes aos 32 meses pós-aplicação, provavelmente, em decorrência do aporte via serapilheira; e diminuição dos teores de Al, nas três profundidades, . O povoamento apresentou teores foliares, para todos os nutrientes analisados, em níveis adequados à nutrição, com possível efeito antagônico entre $\mathrm{Ca}$ e $\mathrm{K}$, aos 36 meses de idade. Quanto à produção de madeira, os tratamentos com tendência à maior produtividade foram das doses de $10 \mathrm{tha}^{-1}+\mathrm{K}+\mathrm{P}$ e $40 \mathrm{tha} \mathrm{h}^{-1}+\mathrm{K}$. De forma geral, o biossólido supriu adequada nutrição ao povoamento, embora acompanhamentos da evolução da fertilidade do solo e da nutrição vegetal sejam necessários em longo dos próximos ciclos de cultivo (condução da brotação). 


\title{
SOIL FERTILITY, MINERAL NUTRITION AND GROWTH MONITORING OF Eucaliptus grandis STANDS FERTILIZED WITH BIOSOLID
}

\author{
Author: GILBERTO NEVES DA ROCHA \\ Adviser: Prof. Dr. JOSÉ LEONARDO DE M. GONÇALVES
}

\section{SUMMARY}

Soil fertility, nutrition and growth of Eucalyptus grandis stands fertilized with biosolid were evaluated in a trial established at the Experimental Station of Itatinga (SP), linked to ESALQ/USP. The experimental design was in randomized blocks, with 4 replicates and 9 treatments, 7 of which were fertilized with biosolid. The treatments were: 1) Control; 2) Mineral fertilization; 3) $5 \mathrm{t} \mathrm{ha}^{-1}$ + K; 4) $10 \mathrm{tha}^{-1}+\mathrm{K}$; 5) $10 \mathrm{tha}^{-1}$; 6) $10 \mathrm{tha}^{-1}+\mathrm{K}+\mathrm{P}$; 7) $15 \mathrm{t} \mathrm{ha}^{-1}+\mathrm{K}$; 8) $20 \mathrm{t} \mathrm{ha}^{-1}$ $+\mathrm{K}$; and 9) $40 \mathrm{tha} \mathrm{h}^{-1}$ of biosolid $+\mathrm{K}$. Soil samples were collected (layers $0-5,5-$ 10 and $10-20 \mathrm{~cm}$ ) to be analyzed, in order to determine the $\mathrm{pH}$ and the amount of macronutrients. From leaf samples, there were analysed the concentration of macro and micronutrients, except B. Growth of the trees was evaluated by the wood biomass. The soil presented the following conditions 32 months after the biosolid application and 36 months after the plantation: increasing amounts of organic carbon and $\mathrm{pH}$, the latter reaching values of 5.8 and 6.2 in the 
treatments of 20 and $40 \mathrm{tha}^{-1}+\mathrm{K}$, respectively, in the layer of $0-5 \mathrm{~cm}$; increasing availability of $\mathrm{P}$ and $\mathrm{Ca}$ in the three layers of soil, associated to the applied biosolid rates, specially in the rates of 20 and $40 \mathrm{tha}^{-1}+\mathrm{K}$, which showed higher values of $\mathrm{P}$ and $\mathrm{Ca}$ availability than with mineral fertilization; decreasing of $\mathrm{S}$ and $\mathrm{K}$ amount during the first thirteen months, probably due to leaching and absorption by roots, but increasing of these elements 32 months after application, probably due to the formation of litter; and decreasing of $\mathrm{Al}$ amounts, in the three layers of the soil, associated to the increasing biosolid rates. For all the nutrients analyzed in the leaves, the stands showed appropriate level of nutrition, with probably antagonic effect among $\mathrm{Ca}$ and $\mathrm{K}, 36$ months after plantation. The treatments with higher wood yields were the ones with rates of $10 \mathrm{tha}^{-1}+\mathrm{K}+\mathrm{P}$ and $40 \mathrm{tha}^{-1}+\mathrm{K}$. In general, the biosolid provided suitable nutrition for the Eucalyptus grandis stands, although it is necessary further monitoring of soil fertility and nutrition. 


\section{INTRODUÇÃO}

O destino das diversas formas de residuos produzidos pela sociedade moderna deixou de ser um problema a ser encarado em futuro distante, para se estabelecer de forma imperativa entre as questões prioritárias da administração pública, privada e pela própria sociedade. A questão tem abrangência ambiental, sanitária e econômica, já que o destino tradicional destes resíduos (rios, lagos, aterros, oceano) implica em riscos ao meio ambiente, à população, além de dispêndios financeiros acentuados com transporte e estocagem dos resíduos em aterros. Assim, nos últimos anos, tem havido grande empenho científico e técnico para a descoberta e desenvolvimento de novas tecnologias de utilização destes residuos, dentre os quais está o lodo produzido nas Estações de Tratamento de Esgoto (ETE).

A disposição do biossólido nos aterros sanitários, de forma contínua e em grande quantidade, diminui rapidamente a vida útil destes locais. Segundo Rocha (1998), "atualmente, existe uma tendência mundial em se priorizar alternativas que promovam a reciclagem do lodo". Na região Metropolitana da Grande São Paulo, vivem cerca de 11,6 milhões de habitantes. Com o crescimento desta população e a ampliação da carga de esgoto tratada pela SABESP em suas ETE's, a previsão de produção de biossólido para o ano de 2005 é de cerca de $566 \mathrm{t} \mathrm{dia}^{-1}$ (base seca) e de $784 \mathrm{t} \mathrm{dia}^{-1}$ para 2015 (Santos et al.,1997). Dentre estas ETE's, está a de Barueri (município de Barueri - SP), considerada a maior da América Latina, que produz cerca de $200 \mathrm{t} \mathrm{dia}^{-1}$ de biossólido, depositados no aterro sanitário Bandeirantes. 
Uma das utilizações potenciais deste composto é o aproveitamento como fonte de nutrientes para culturas agrícolas e florestais. O biossólido tem se mostrado com grande aptidão para recondicionar as propriedades químicas, físicas e biológicas do solo (Companhia de Saneamento do Paraná, 1997; Melo \& Marques, 2000).

A tendência de uso do biossólido em culturas florestais em várias partes do mundo, principalmente de regiões temperadas, já existe. Porém, há a necessidade de ampliação das pesquisas para condições de solo e clima tropicais. No Estado de São Paulo, vastas áreas destinadas a florestas poderiam absorver grande parte do biossólido produzido nas ETE's. A primeira etapa de um experimento neste sentido foi realizada no periodo de 1998 a 2000, por Vaz \& Gonçalves (2002), os quais obtiveram resultados promissores em relação ao desenvolvimento de um povoamento de Eucalyptus grandis fertilizado com doses crescentes de biossólido. A implantação da segunda etapa deste experimento fez-se necessária, já que processos envolvendo o sistema resíduo-solo-floresta são, em grande parte, lentos e complexos, exigindo informações em escala espacial e, sobretudo, temporal, para melhor avaliação do potencial do biossólido na fertilização de culturas de E. grandis.

\subsection{Justificativa}

Não há dados suficientes do comportamento do biossólido em plantações de florestas homogêneas, sob condições tropicais, que possam participar da estruturação de uma política de uso de biossólido mais freqüente. Assim, este trabalho pretendeu contribuir para maior esclarecimento do comportamento do biossólido ao longo do tempo, em termos de fertilidade do solo, nutrição e desenvolvimento de um povoamento de $E$. grandis. 


\subsection{Objetivos}

Avaliar os efeitos da aplicação de doses crescentes de biossólido na fertilidade do solo, na nutrição mineral e no crescimento de povoamentos de Eucalyptus grandis, comparativamente a povoamentos sob efeito de adubação mineral, só ou combinada com biossólido.

\subsection{Hipóteses}

1) O biossólido eleva a fertilidade do solo gradualmente, ao longo do tempo; e

2) A aplicação do biossólido propicia nutrição adequada e influi positivamente no crescimento de plantações de E. grandis. 


\section{REVISÃO DE LITERATURA}

\subsection{Definição de biossólido}

Segundo definição dada pela ABNT (Associação Brasileira de Normas Técnicas: NBR 10004, 1987), lodo de esgoto é o "resíduo no estado sólido e semi-sólido, que resulta da comunidade e origem industrial, doméstica, hospitalar, comercial, agrícola e de serviços de varrição. Ficam incluídos nesta definição os lodos provenientes de sistemas de tratamento de água, aqueles gerados em equipamentos e instalações de controle de poluição, bem como determinados líquidos cujas particularidades tornem inviável o seu lançamento na rede pública de esgoto ou corpos d'água, ou exijam para isso soluções técnicas e economicamente viáveis face a melhor tecnologia disponível".

Segundo a Companhia de Tecnologia de Saneamento Ambiental (1999), biossólido refere-se ao lodo resultante do sistema de tratamento biológico de despejos líquidos, com características tais que atendam às condições do manual técnico da Companhia de Tecnologia de Saneamento Ambiental/P.4230, 1999. Por convenção, o termo biossólido foi aceito pela comunidade científica brasileira para designar o lodo de esgoto doméstico que tenha passado por uma decomposição microbiológica parcial e que seja passivel de utilização, sem criar impactos negativos ao ambiente.

De modo geral, o biossólido é uma mistura de sólidos orgânicos e inorgânicos, diluídos em água $(60$ a $75 \%$ de umidade, dependendo do procedimento), resultado da coagulação microbiológica dos sistemas biológicos de tratamento do esgoto. A porção mineral resulta da floculação dos sólidos 
inorgânicos em suspensão e a porção orgânica, parte por biomassa bacteriana viva e parte por sólidos voláteis suspensos sem atividade biológica (Fernandes, 2000). Desta forma, é rico em matéria orgânica e nutrientes, os quais possuem papel fundamental na recuperação das propriedades físicas e químicas de solos desgastados pelo uso intensivo.

\subsection{Biossólido como otimizador da fertilidade do solo}

Segundo Primavesi (1988), "o solo não é somente suporte para plantas e adubos, mas sim, um sistema dinâmico de complexas inter-relações recíprocas entre seus componentes físicos, químicos e biológicos". Assim, ações que possibilitem melhorias, não apenas na quantidade e qualidade de um só fator, mas da estrutura ecológica como um todo, aumentam a saúde do sistema implantado de forma mais concreta. O biossólido, desta maneira, tem mostrado ser modificador de diversos fatores. De modo geral, tem sido constatado que a adição de biossólido altera as propriedades físicas do solo, melhorando-o sob a ótica agronômica e florestal, já que diminui sua densidade e aumenta a porosidade e a capacidade de retenção de água (Jorge et al., 1991; Companhia de saneamento do Paraná, 1997; Melo \& Marques, 2000). Pode, ainda, alterar a quantidade de matéria orgânica, o $\mathrm{pH}$, a CTC e os teores de macronutrientes, principalmente $\mathrm{N}, \mathrm{P}$ e $\mathrm{Ca}$, além de propiciar incremento de produtividade em diversas culturas (Santos, 1979; Phillips et al., 1986; Berton et al., 1989; Melo et al., 1994; Bevacqua \& Mellano, 1994; Dutch \& Wosltenholme, 1994; Oliveira et al., 1995; Folle et al., 1995; Silva, 1995; Ayuso et al., 1996; Andreoli et al., 1997; Zhang \& Xue, citados por Wang, 1997; Skousen \& Klinger, 1998; Sort \& Alcaniz, 1999).

Somado a isto, estudos com biossólido têm mostrado ser este uma fonte energética potencial para a microbiota do solo, importante agente em muitos dos processos que influenciam a fertilidade do solo. $O$ biossólido adicionado ao solo pode provocar aumento da atividade e da biomassa microbiana (Banerjee 
et al., 1997; Lambais e Souza, 2000; Cardoso \& Fortes-Neto, 2000; Carmo, 2001).

Assim, a adição de biossólido em solos florestais de baixa fertilidade poderá propiciar um ambiente com estrutura e fertilidade de solo gradativamente melhores. Um dos efeitos benéficos da adição do biossólido em solos florestais, principalmente quando arenosos, é a disponibilização de nutrientes de forma mais lenta que a adubação mineral. Isto elimina, em parte, o problema de lixiviação excessiva, freqüente nas adubações convencionais.

\subsection{Potencial do uso do biossólido na atividade florestal}

O uso de biossólido tem apontado para melhorias da produção florestal, constatados em estudos na Austrália, Canadá e EUA (McNab \& Berry, 1985; Weetman et al., 1993; McDonald et al., 1994; Polglase \& Myers, 1995). A United States of Agency Protection Environment (1993) tem incentivado o uso de biossólido para incremento da produtividade florestal norte-americana (Santos et al., 1997). Em países da Europa e América do Norte, o uso do lodo de esgoto é prática usual (DA ROS et al., 1993).

No Brasil, há pouca informação sobre a aplicação do biossólido em sistemas florestais, embora estes sistemas tenham alcançado proporções significativas em área nos últimos anos, chegando a ocupar cerca de 4,8 milhões de hectares, sendo cerca de 3 milhões com Eucalyptus e 1,8 milhões com Pinus. No Estado de São Paulo, a área florestada abrange cerca de 780 mil hectares (74\% de Eucalyptus e $26 \%$ de Pinus) (Sociedade Brasileira de Silvicultura, 1991).

Gonçalves et al. (1997) caracterizaram o solo das áreas destinadas à atividade florestal no Brasil como estando, geralmente, em avançado estádio de intemperização sendo, conseqüentemente, de baixa fertilidade; os materiais de origem mais comuns sendo as rochas sedimentares, principalmente os arenitos, com baixa disponibilidade de minerais primários; e os minerais de argila sendo 
basicamente óxidos de Fe e Al, caulinita e materiais amorfos. Essa composição mineralógica, segundo os autores, faz com que as reservas de nutrientes na forma de minerais primários sejam pequenas, a capacidade de troca de cátions seja baixa, a capacidade de fixação de $\mathrm{P}$ seja média a alta e a permeabilidade $\mathrm{e}$ o potencial de lixiviação de bases dos solos, muito elevados. Os teores de macro e micronutrientes são considerados baixos ou muito baixos, com grandes implicações sobre os potenciais de uso e manejo dos solos. Sob tais condições, as colheitas sucessivas de madeira de espécies com grande capacidade de extração de nutrientes, como o eucalipto e o pinus, teriam grandes impactos sobre as pequenas disponibilidades e reservas minerais dos solos. Isso freqüentemente leva a quedas de produtividade, já que a reposição de nutrientes via fertilização mineral, normalmente, é menor do que a exportação de nutrientes via madeira.

Áreas florestais possuem alguns aspectos que as colocam como potenciais candidatas à utilização de boa parte do biossólido produzido nas ETE's: a) as florestas ocupam extensas áreas e eventuais diminuições no uso de fertilizantes minerais podem constituir substanciais reduções de custos na produção florestal; b) amplas áreas florestais sofrem de deficiências ou desbalanços nutricionais, especialmente $N$ e P (a carência de nutrição adequada é um dos principais fatores limitantes da produtividade florestal em todo mundo); c) as áreas florestais, de modo geral, não estão sujeitas a enchentes periódicas e são localizadas em sítios bem drenados; d) a maioria das florestas, sobretudo as plantadas, não estão associadas à produção de alimentos, o que permite a aplicação regular de biossólido com baixos riscos à saúde pública; e e) os ecossistemas florestais têm alguns atributos desejáveis para receber o biossólido, tais como, (i) grande produção e distribuição de carbono orgânico em seus componentes, capazes de imobilizar grandes quantidades de nutrientes e metais pesados, (ii) boa drenagem dos solos, minimizando o potencial de arrastamento de constituintes indesejáveis do biossólido via enxurrada e (iii) grande quantidade de raízes perenes explorando amplo volume 
do solo, permitindo absorver nutrientes e metais pesados durante todo o ano (regiões tropicais) ou parte do ano (regiões temperadas). Soma-se a estas razões o fato de sistemas florestais poderem receber aplicação de biossólido apenas uma única vez a cada ciclo de produção, mantendo os teores de metais pesados dentro dos limites aceitáveis, e os nutrientes contidos no biossólido serem lentamente liberados (Carvalho \& Barral, 1981) e absorvidos, tendo seu efeito prolongado na cultura (efeito desejável em culturas perenes).

O uso do biossólido possui diversos aspectos positivos, como salientados acima. Porém, a presença de metais pesados e de patógenos na composição do biossólido, ainda com potencial de atividade, condiciona seu uso. Estes dois aspectos levaram ao desenvolvimento de normas e recomendações para a aplicação do biossólido (Henry et al., 1994; Companhia de saneamento do Paraná, 1997; Companhia de Tecnologia de Saneamento Ambiental, 1999). Estas normas e recomendações consideram, entre outras, a classificação do biossólido quanto ao grau de metais pesados e patógenos, o tipo de cultura implantada, a declividade do terreno, as características do solo, a proximidade de lençol freático e cursos d'água, além da drenagem, a proximidade de residências e a utilização da área pela população. 


\section{MATERIAL E MÉTODOS}

\subsection{Caracterização da área experimental}

Este trabalho foi conduzido na Estação Experimental de Itatinga,

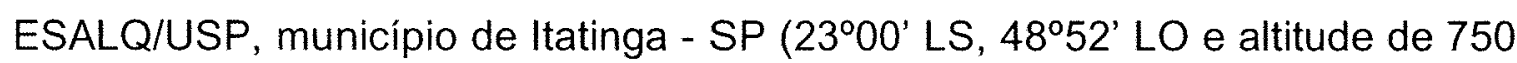
$\mathrm{m}$ ), distando aproximadamente $220 \mathrm{Km}$ da cidade de São Paulo e $170 \mathrm{Km}$ da cidade de Piracicaba - SP. O solo da área foi caracterizado como Latossolo Vermelho Amarelo distrófico psamítico, textura arenosa (areia $=830$, silte $=50$ e argila $=120 \mathrm{~g} \mathrm{~kg}^{-1}$ na camada $0-20 \mathrm{~cm}$ ), distrófico e plano. A vegetação natural da região é o cerrado e as condições edafoclimáticas e florísticas da mesma são representadas por extensos blocos de florestas homogêneas plantadas no planalto ocidental paulista. O clima é do tipo Cwa, segundo classificação de köeppen, ou seja, mesotérmico de inverno seco, em que a temperatura média do mês mais frio (julho) é inferior a $18^{\circ} \mathrm{C}$, e a do mês mais quente (janeiro), superior a $22^{\circ} \mathrm{C}$. A precipitação média anual da área é de, aproximadamente, $1579 \mathrm{~mm}$, com $57 \%$ concentrada nos meses de dezembro a março. Na Tabela 1, são apresentados alguns atributos químicos do solo. A espécie utilizada no experimento foi o Eucalyptus grandis Hill Ex Maiden, procedente de Bounville - Coff's Harbour, Austrália. O plantio com mudas formadas a partir de sementes foi realizado em março de 1998, com espaçamento $3,0 \times 2,0 \mathrm{~m}$. O preparo do solo consistiu em uma passagem de um rolo-faca, para picar os galhos do cultivo anterior, seguido da abertura de um sulco de $30 \mathrm{~cm}$ de profundidade com escarificador monohaste. Em seguida, 
fez-se o plantio neste sulco. O replantio das mudas que morreram foi realizado 35 dias após o plantio.

Tabela 1. Alguns atributos químicos ${ }^{\star}$ do solo por ocasião da instalação do experimento.

\begin{tabular}{|c|c|c|c|c|c|c|c|c|c|c|c|c|}
\hline Prof. & $\mathrm{pH}$ & MO & $P$ & $\mathrm{~K}$ & $\mathrm{Ca}$ & $\mathrm{Mg}$ & $\mathrm{H}+\mathrm{Al}$ & $\mathrm{Al}$ & SB & $T$ & $\mathrm{~V}$ & $\mathbf{m}$ \\
\hline $\mathrm{cm}$ & $\mathrm{CaCl}_{2}$ & $\mathrm{~g} \mathrm{dm}^{-3}$ & $\mathrm{mg} \mathrm{dm}^{-3}$ & - & 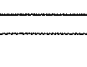 & $-n$ & $\mathrm{nol}_{c} \mathrm{dm}^{-3}$ & & & & $\%$ & $\%$ \\
\hline $0-5$ & 3,6 & 56 & 2 & 0,9 & 3 & 2 & 92 & 19 & 6 & 97 & 5 & 79 \\
\hline $5-10$ & 3,8 & 18 & 1 & 0,9 & 2 & 2 & 53 & 12 & 5 & 59 & 10 & 68 \\
\hline $10-20$ & 3,8 & 15 & 1 & 0,9 & 4 & 1 & 45 & 10 & 5 & 50 & 11 & 65 \\
\hline & \multicolumn{2}{|c|}{$\mathrm{Cu}$} & $\mathrm{Zn}$ & \multicolumn{3}{|c|}{$M n$} & $\mathrm{Fe}$ & & $-\mathrm{SO}_{4}{ }^{2-}$ & & \multicolumn{2}{|c|}{ B } \\
\hline \multicolumn{13}{|l|}{$\mathrm{cm}$} \\
\hline $0-5$ & \multicolumn{2}{|c|}{0,5} & \multicolumn{2}{|l|}{0,5} & \multicolumn{2}{|l|}{2,4} & 123 & \multicolumn{3}{|c|}{12,8} & \multicolumn{2}{|c|}{0,2} \\
\hline $5-10$ & \multicolumn{2}{|c|}{0,6} & \multicolumn{2}{|l|}{0,3} & \multicolumn{2}{|l|}{0,5} & 76 & \multicolumn{3}{|c|}{13,9} & \multicolumn{2}{|c|}{0,2} \\
\hline $10-20$ & \multicolumn{2}{|c|}{0,7} & \multicolumn{2}{|l|}{0,3} & \multicolumn{2}{|l|}{0,4} & 67 & \multicolumn{3}{|c|}{26,6} & \multicolumn{2}{|c|}{0,2} \\
\hline
\end{tabular}

* Análise segundo métodos descritos por Raij et al.(1987)

\subsection{Caracterização do biossólido}

A caracterização do biossólido usado no experimento encontra-se na Tabela 2. Trata-se de um residuo produzido por digestão aeróbica (fase de decantação) e anaeróbica (fase final no digestor). Antes de ser desidratado nas prensas hidráulicas, passou por um processo de adensamento e higienização com cal extinta (250 kg t-1 de biossólido) e cloreto férrico (100 kg t-1 de biossólido). O biossólido gerado foi classificado como do tipo $\mathrm{B}$ (Companhia de Tecnologia de Saneamento Ambiental, 1999). Possui grande quantidade de matéria orgânica ( $30 \%$ em média), relação $\mathrm{C}: \mathrm{N}$ de 4,3 , umidade em torno de $60 \%$ e pH $\left(\mathrm{em} \mathrm{H}_{2} \mathrm{O}\right)$ próximo a 12. 
Tabela 2. Composição química (elementos totais, base seca $-65^{\circ} \mathrm{C}$ ) do biossólido tipo B pela Estação de Tratamento de Esgoto de Barueri, SP.

\begin{tabular}{cccc}
\hline Elemento & Concentração & Elemento & Concentração \\
\hline $\mathrm{C}\left(\mathrm{g} \mathrm{kg}^{-1}\right)$ & 114,0 & $\mathrm{~S}\left(\mathrm{~g} \mathrm{~kg}^{-1}\right)$ & 6,0 \\
$\mathrm{~N}\left(\mathrm{~g} \mathrm{~kg}^{-1}\right)$ & 26,6 & $\mathrm{Fe}\left(\mathrm{mg} \mathrm{kg}^{-1}\right)$ & 39200 \\
$\mathrm{P}\left(\mathrm{g} \mathrm{kg}^{-1}\right)$ & 9,5 & $\mathrm{Zn}\left(\mathrm{mg} \mathrm{kg}^{-1}\right)$ & 1500 \\
$\mathrm{~K}\left(\mathrm{~g} \mathrm{~kg}^{-1}\right)$ & 1,3 & $\mathrm{Mn}\left(\mathrm{mg} \mathrm{kg}^{-1}\right)$ & 300 \\
$\mathrm{Ca}\left(\mathrm{g} \mathrm{kg}^{-1}\right)$ & 95,0 & $\mathrm{Cd}\left(\mathrm{mg} \mathrm{kg}^{-1}\right)$ & 21 \\
$\mathrm{Mg}\left(\mathrm{g} \mathrm{kg}^{-1}\right)$ & 3,0 & $\mathrm{~Pb}\left(\mathrm{mg} \mathrm{kg}^{-1}\right)$ & 200 \\
$\mathrm{Na}\left(\mathrm{g} \mathrm{kg}^{-1}\right)$ & 0,5 & & \\
\hline
\end{tabular}

\subsection{Tratamentos e delineamento experimental}

Os métodos aplicados neste trabalho foram os mesmos utilizados durante a primeira fase do projeto ( $V a z$ \& Gonçalves, 2002), como descritos a seguir, por dois motivos: (i) estes mostraram-se adequados ao desenvolvimento do trabalho; e (ii) proporcionam uma melhor comparação e conexão dos resultados aqui encontrados aos do trabalho realizado na primeira fase.

O experimento foi instalado usando-se o delineamento experimental em blocos ao acaso, com nove tratamentos e quatro repetições. Cada parcela experimental foi composta por 100 plantas distribuídas em 10 linhas com 10 plantas em cada linha, em espaçamento de plantio igual a $3 \times 2 \mathrm{~m}$, totalizando $600 \mathrm{~m}^{2}$ por parcela. O experimento contou, então, com 2,2 ha de área plantada. Somente as 36 plantas centrais foram consideradas nas avaliações dendrométricas e as demais, deixadas como bordadura dupla. A relação de tratamentos experimentais é apresentada a seguir:

1.Testemunha - sem fertilização mineral e sem aplicação de biossólido;

2. Fertilização mineral $-1,5 \mathrm{t} \mathrm{ha}^{-1}$ de calcário dolomítico (a lanço em área total), $110 \mathrm{~kg} \mathrm{ha}^{-1}$ de 0-45-0 (sulco de plantio), $150 \mathrm{~kg} \mathrm{ha}^{-1} \mathrm{de}$ 10-20-10 (sulco de plantio), $80 \mathrm{~kg} \mathrm{ha}^{-1}$ de 20-0-20 (45 dias pósplantio aplicado em meia lua ao redor da muda), $180 \mathrm{~kg} \mathrm{ha}^{-1} \mathrm{de}$ 
$16-0-32+0,3 \% \mathrm{~B}+0,5 \%$ de $\mathrm{Zn}$ (6 meses pós-plantio aplicado numa faixa de $40 \mathrm{~cm}$ na entrelinha de plantio) e $240 \mathrm{~kg} \mathrm{ha}^{-1}$ de 16 $0-32+0,3 \% \mathrm{~B}+0,5 \%$ de $\mathrm{Zn}$ (12 meses pós-plantio aplicado numa faixa de $40 \mathrm{~cm}$ na entrelinha de plantio);

3. 5 t ha ${ }^{-1}$ de biossólido (base seca), com suplementação de $\mathrm{K}$;

4. 10 t ha $^{-1}$ de biossólido (base seca), com suplementação de $K$;

5. 10 t ha $^{-1}$ de biossólido (base seca), sem suplementação de $K$;

6. $10 \mathrm{t} \mathrm{ha}^{-1}$ de biossólido (base seca), com suplementação de $\mathrm{K}$ e $\mathrm{P}$;

7. $15 \mathrm{t} \mathrm{ha}^{-1}$ de biossólido (base seca), com suplementação de $K$;

8. 20 t ha $^{-1}$ de biossólido (base seca), com suplementação de $\mathrm{K}$;

9. $40 \mathrm{t} \mathrm{ha}^{-1}$ de biossólido (base seca), com suplementação de K;

Os tratamentos $3,4,6,7,8$ e 9 receberam suplementação de $\mathrm{K}$ $\left(\mathrm{KCl}, 60 \%\right.$ de $\left.\mathrm{K}_{2} \mathrm{O}\right)$, até que as quantidades de $\mathrm{K}$ contidas no biossólido somadas às do fertilizante potássico ficassem iguais à do tratamento $2(125 \mathrm{~kg}$ ha $^{-1}$ de K). O tratamento 6 recebeu suplementação de $\mathrm{P}$ (superfosfato triplo), de modo que a quantidade de $P$ contida no biossólido mais a do fertilizante fosfatado ficasse igual à do tratamento $2\left(80 \mathrm{~kg} \mathrm{ha}^{-1}\right.$ de $\left.\mathrm{P}_{2} \mathrm{O}_{5}\right)$. Em meados de julho de 1998, o resíduo foi aplicado com sua umidade original (60\%), em faixas de $2 \mathrm{~m}$, sobre a superfície do solo, reservando uma distância de $0,5 \mathrm{~m}$ de cada lado da linha de plantio do eucalipto. A aplicação foi feita em carreta de distribuição acionada por bomba hidráulica de baixa vazão, que movimentava uma esteira localizada na base da carreta, promovendo a aplicação do resíduo. A suplementação de $\mathrm{K}$ foi feita parceladamente: a primeira parcela de $\mathrm{KCl}, 35$ $\mathrm{kg} \mathrm{ha}^{-1}$ de $\mathrm{K}_{2} \mathrm{O}$, foi aplicada em meia lua ao redor das plantas, seis meses após o plantio; a segunda, $58 \mathrm{~kg} \mathrm{ha}^{-1}$ de $\mathrm{K}_{2} \mathrm{O}$; e a terceira parcela, o que restou, foram aplicadas em faixas de $40 \mathrm{~cm}$ de largura, no centro das entrelinhas, $12 \mathrm{e}$ 18 meses após o plantio, respectivamente. O superfosfato triplo usado no tratamento 6 foi aplicado no sulco de plantio. 
Realizou-se uma capina química, a base de glifosato, um mês após o plantio, e uma roçada manual, treze meses após esta capina. O controle de formigas cortadeiras foi feito pré- e pós-implantação do povoamento, com uso de iscas formicidas. Aos 12 meses de idade, foi realizada aplicação do fungicida Bayfidan $\left(2 \mathrm{~kg} \mathrm{ha}^{-1}\right)$ para controle de ferrugem.

\subsection{Medição das condições climáticas}

Os dados pluviométricos, de temperatura máxima, média e mínima e de umidade relativa, durante o período de condução do experimento, foram coletados numa estação meteorológica situada na área experimental.

\subsection{Monitoramento da fertilidade do solo}

As características químicas do solo foram determinadas para os tratamentos sob efeito de $0,10,20$ e $40 \mathrm{t} \mathrm{ha}^{-1}$ de biossólido $+\mathrm{K}$ aplicado, de adubação mineral e de $10 t$ ha $^{-1}$ de biossólido $+K+P$, nas camadas de $0-5,5-$ 10, 10-20 cm de profundidade. Foram avaliados: $\mathrm{pH}$, carbono orgânico, fósforo disponivel, enxofre, cálcio, magnésio, potássio e alumínio trocável, segundo Raij et al. (2001). Os micronutrientes ( $\mathrm{Cu}, \mathrm{Fe}, \mathrm{Mn}$ e $\mathrm{Zn}$ ) foram analisados segundo método proposto por Lindsay \& Norvell (1978).

Para a amostragem de solo, foram coletadas dez amostras simples por parcela em um transecto diagonal à área útil da parcela, nas entrelinhas de plantio (onde foi aplicado o biossólido). Estas amostras deram origem a uma amostra composta.

\subsection{Avaliação do estado nutricional}

Para se avaliar o estado nutricional das árvores, cerca de $200 \mathrm{~g}$ de folhas, localizadas na região intermediária dos galhos, estes pertencentes ao 
terço superior da árvore, foram amostrados, em todos os tratamentos. As amostras de folhas foram pesadas e colocadas em estufa de circulação forçada a $65{ }^{\circ} \mathrm{C}$ por 72 horas, para posterior determinação dos teores de $\mathrm{N}, \mathrm{P}, \mathrm{K}, \mathrm{Ca}$, Mg e S, segundo métodos descritos por Sarruge \& Haag (1974).

\subsection{Produção de madeira}

Para se estimar a produção de madeira, foi abatida uma árvore média quanto ao diâmetro à altura do peito, por parcela, para todos os tratamentos. Foram adotados os seguintes procedimentos:

a) Nas árvores abatidas, tomou-se os diâmetros com e sem casca, das bases das árvores até a altura em que este obtivesse um valor de $3 \mathrm{~cm}$;

b) Com os valores das medições efetuadas foram calculados os volumes do tronco com e sem casca através da fórmula de Smallian:

$$
V t=\left(T^{2}+B^{2}\right) \times L \times C, \text { onde: }
$$

$V t=$ volume total da árvore $\left(\mathrm{m}^{3}\right) ; \mathrm{L}=$ comprimento de cada torete $(\mathrm{m}) ; \mathrm{T}=$ raio do topo $(\mathrm{cm}) ; \mathrm{B}=$ raio da base $(\mathrm{cm}) ;$ e $\mathrm{C}=0,0001570796$ (constante).

c) Pela diferença entre os volumes de madeiras com e sem casca, obteve-se o volume de casca de cada árvore. Através do volume de casca e de sua densidade pôde-se deduzir o peso de casca de todos os tratamentos, determinando, então, o peso do fuste sem casca.

\subsection{Análise dos dados}

Os dados foram submetidos, quando convenientes, à análise estatística descritiva, à análise de variância (ANOVA), à análise de regressão e ao Teste de Tukey. 


\section{RESULTADOS E DISCUSSÃO}

\subsection{Monitoramento das condições climáticas}

Na Figura 1 estão representados, ao longo do tempo, o plantio das mudas, a aplicação do biossólido, as amostragens de solo, as avaliações nutricionais, as precipitações e temperaturas médias mensais e os excedentes e deficiências hídricas da área. Durante o decorrer deste experimento, com exceção de dois períodos (março a novembro de 1998 e março a junho de 2000), não foram registrados significativos déficits hídricos. A primeira e terceira amostragens de solo foram precedidas por elevadas precipitações e temperaturas médias, sendo a segunda precedida por período de baixas precipitações e temperaturas médias. As avaliações nutricionais foram realizadas em periodos sem deficiência hídrico. Não foi verificado déficit hídrico nos seis meses que antecederam a primeira e a segunda avaliações nutricionais e nos oito meses que antecederam a terceira avaliação.

\subsection{Fertilidade do Solo}

Os teores de carbono orgânico no solo, antes da aplicação do biossólido, foram de 33,10 e $9 \mathrm{~g} \mathrm{dm}^{-3}$ nas camadas $0-5,5-10$ e $10-20 \mathrm{~cm}$, respectivamente. Aos seis meses pós-aplicação do biossólido, na camada 0-5 $\mathrm{cm}$, seus teores, nos tratamentos que receberam 10,20 e $40 \mathrm{t} \mathrm{ha}^{-1}+\mathrm{K}$ de biossólido, foram menores que os valores iniciais (Figura 2). Segundo Vaz \& Gonçalves (2002), a adição de biossólido ao solo estaria estimulando a atividade microbiana, a qual, atuando sobre frações orgânicas de fácil decomposição, seria uma das principais causas dessa depleção de teores de 
MO. A baixa relação $\mathrm{C}: \mathrm{N}(4,3)$ e a boa disponibilidade de nutrientes contidos no biossólido são fatores intensificadores da atividade microbiológica neste resíduo e no solo, logo após sua aplicação.

Treze meses pós-aplicação do biossólido, na mesma camada $(0-5 \mathrm{~cm})$, os teores de carbono orgânico nos tratamentos 20 e $40 \mathrm{t} \mathrm{ha}^{-1}+\mathrm{K}$ de biossólido foram semelhantes aos observados na testemunha e, aos 32 meses, não houve diferenças entre tratamentos, embora haja tendência de elevação do teor de carbono orgânico ao elevar-se as doses de biossólido. Tanto a depleção inicial como o aumento dos teores de carbono orgânico devem estar relacionados, respectivamente, com a disponibilidade e a exaustão de fatores intensificadores da atividade microbiológica, sendo o principal a relação $\mathrm{C}: \mathrm{N}$. Também, devem estar contribuindo para a elevação destes teores, na camada $0-5 \mathrm{~cm}$ de solo, o aporte de ácidos e outros resíduos orgânicos oriundos da reciclagem de biomassa microbiana e raizes finas. O comportamento dos teores de carbono orgânico no solo, observados na camada superficial dos tratamentos que receberam as maiores doses de biossólido, tem boa relação com o padrão de atividade microbiológica observada por Fortes Neto (2000), em um solo que recebeu biossólido. Este pesquisador dividiu em quatro etapas o processo de degradação do biossólido: após uma etapa inicial de queda na atividade microbiana (adaptação às novas condições do solo), segue uma etapa de aumento desta atividade, entendida como uma resposta à oferta de frações lábeis de matéria orgânica $(\mathrm{MO})$ e de nutrientes contidas no biossólido. Nesta fase, altas taxas de mineralização da $\mathrm{MO}$ do solo podem ocorrer. Posteriormente, há uma etapa de estabilidade da atividade microbiológica. Com a depleção das quantidades de substrato energético e de nutrientes disponíveis, ocorre a última etapa, de declínio da atividade microbiológica, quando os teores de MO do solo podem elevar-se. 

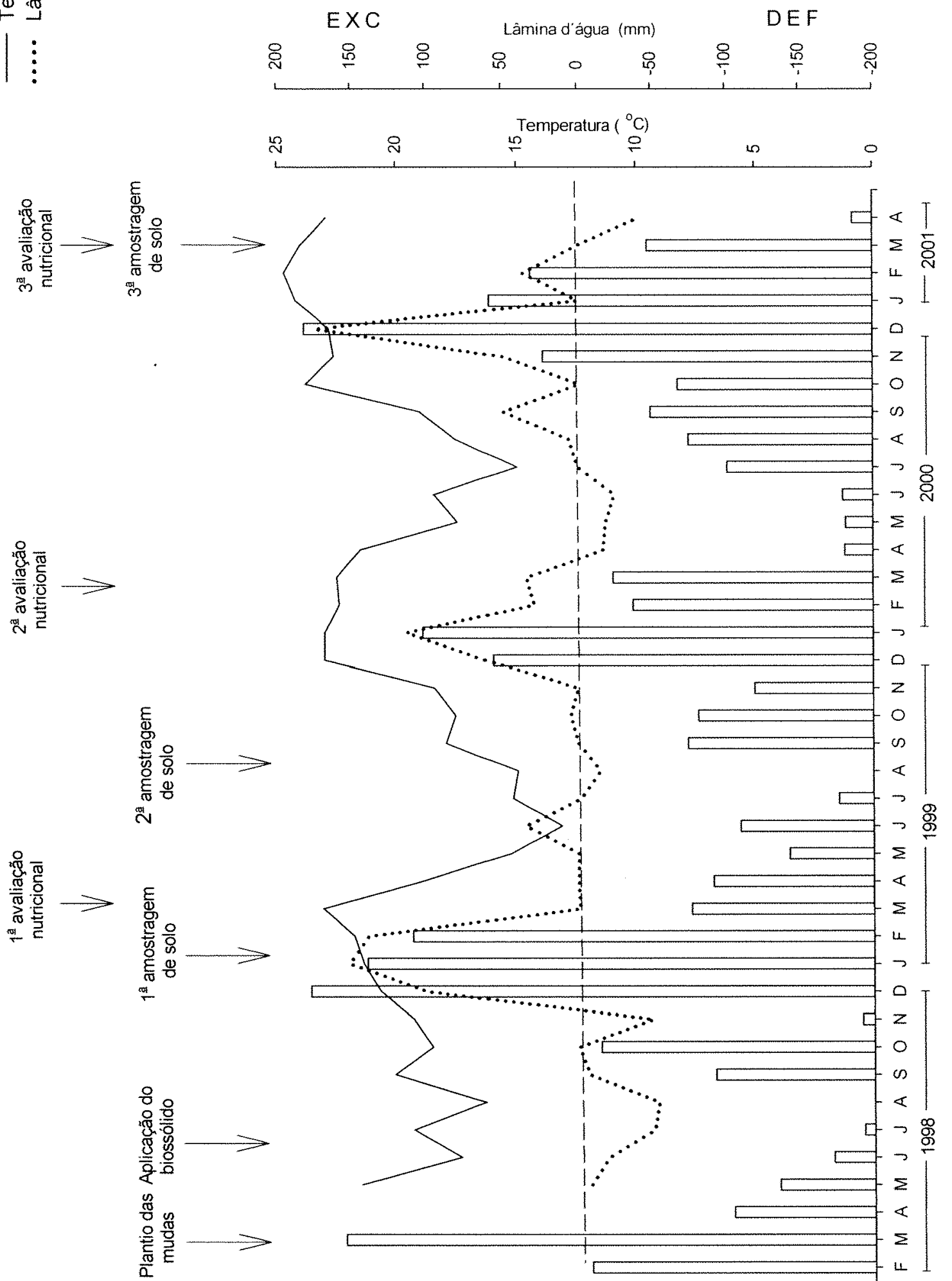

$\angle$
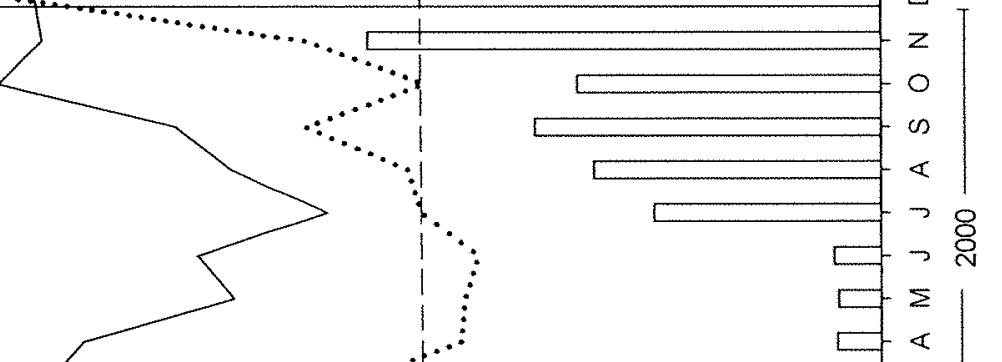

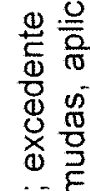

亏

옹

니을

$\infty \frac{\pi}{2}$

항

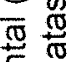

둥

든

वे

।

응

ब.

.

$\Phi$ 迹

完

농응

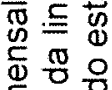

잉

응

है

芭

त.

융응

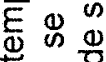

o 15

밈

(⿻)

음

这总

1

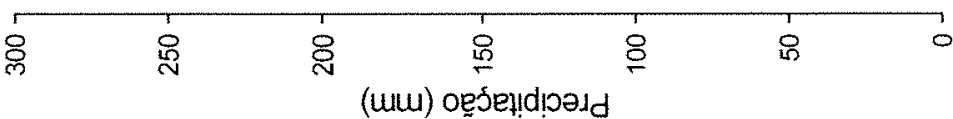

음 
Nas profundidades 5-10 e 10-20 cm, observou-se tendência de elevação dos teores de carbono orgânico com a elevação das doses de biossólido, aos 32 meses pós-aplicação deste resíduo, sendo significativas as diferenças entre os tratamentos sob efeito de $40 \mathrm{tha}^{-1}+\mathrm{K}$ de biossólido e da adubação mineral, para as duas profundidades.

Em relação à testemunha, a diminuição do teor de carbono orgânico na profundidade de $0-5 \mathrm{~cm}$, comparado ao teor inicial, observada aos seis e, mais evidente, aos 13 meses pós-aplicação, pode estar associada à mineralização da matéria orgânica do solo e ao baixo aporte de matéria orgânica, devido ao corte raso dos povoamentos adultos de eucalipto existentes na área, antes da instalação do experimento. Aos 32 meses, o teor de carbono orgânico na testemunha, assim como nos demais tratamentos, foi superior aos anteriores, decorrendo, provavelmente, do aporte de húmus oriundo da decomposição de raízes finas e de serrapilheira, intensificado após o início da ciclagem biogeoquímica (fase de fechamento de copas).

O decréscimo dos teores de carbono orgânico na camada superficial, nos tratamentos 10, 20 e $40 \mathrm{tha}^{-1}+\mathrm{K}$, aos seis meses, também pode estar, indiretamente, associado ao aumento de $\mathrm{pH}$ (Figura 3), pois este elevou-se 0,2, 0,4 e 0,7 unidade de $\mathrm{pH}$, seis meses pós-aplicação do biossólido, respectivamente. Isto pode ter contribuído para o aumento da atividade dos microrganismos, refletindo na velocidade de mineralização do carbono orgânico. Aos 32 meses pós-aplicação do biossólido, observou-se grande aumento do $\mathrm{pH}$ nestes tratamentos, passando de 3,6 (antes da aplicação) para 4,6, 5,8 e 6,1, respectivamente. Entre os tratamentos, houve diferenças significativas, na seguinte ordem: $40 \mathrm{tha}^{-1}+\mathrm{K} \geq 20 \mathrm{tha}^{-1}+\mathrm{K}>10 \mathrm{tha}^{-1}+\mathrm{K} \geq$ $10 \mathrm{tha}^{-1}+\mathrm{K}+\mathrm{P}>$ adubação mineral $\geq$ testemunha. Este aumento de $\mathrm{pH}$ pode ter três causas principais: a) solubilização lenta da cal extinta (adicionada ao biossólido durante o processo de adensamento e higienização), devido à sua baixa solubilidade; b) aporte no solo de compostos orgânicos, os quais complexam o $\mathrm{Al}$, aumentando $\mathrm{o} \mathrm{pH}$; e c) adição ao solo de produtos do 
metabolismo microbiano, os quais podem ter efeitos alcalinizantes (Rosato, 1978; Costa, 1983; Maria, 1986). Como possíveis causas do longo tempo demandado para a elevação do $\mathrm{pH}$ no solo, a despeito das altas doses de bases aplicadas e da natureza permeável do solo, pode-se enumerar: a) a diminuição do efeito tamponante (Kiehl, 1985) da materia orgânica adicionada, à medida que a decomposição do resíduo evoluiu; b) a demora na solubilização, lixiviação e interação do $\mathrm{Ca}$ com o complexo de troca iônica do solo - se o biossólido tivesse sido incorporado, certamente esse efeito teria sido mais rápido -; e c) a ocorrência de precipitações pluviométricas insuficientes para rápida solubilização do Ca (Figura 1). Andrade (1999), avaliando este experimento até os 360 dias pós-aplicação do biossólido, chama a atenção para a necessidade de tempo mais extenso para que houvesse alterações relativas ao $\mathrm{pH}$. Como causas desta necessidade, estariam o menor contato das partículas de biossólido com o solo, nesta época, e a difícil hidratação dessas partículas após secagem.

Nas camadas inferiores, entre 5 e $20 \mathrm{~cm}$, somente na amostragem realizada aos 32 meses pós-aplicação do biossólido, foi constatada considerável elevação do $\mathrm{pH}$ nos tratamentos que receberam as maiores doses (20 e $40 \mathrm{t} \mathrm{ha}^{-1}$ ), reflexo da lixiviação do Ca.

Aos 32 meses pós-aplicação do biossólido, observou-se, nas três profundidades monitoradas, elevados teores de $\mathrm{P}$ no solo, nos tratamentos que receberam as maiores doses aplicadas (Figura 4). Por exemplo, os teores de P-assimilável elevaram-se de 12 para 199 e de 25 para $259 \mathrm{mg} \mathrm{dm}^{-3}$ na camada $0-5 \mathrm{~cm}$; de 13 para 108 e de 12 para $224 \mathrm{mg} \mathrm{dm}^{-3}$ na camada $5-10 \mathrm{~cm}$; e de 7 para 35 e de 8 para $96 \mathrm{mg} \mathrm{dm}^{-3}$ na camada $10-20 \mathrm{~cm}$ de solo, respectivamente, nos tratamentos 20 e $40 \mathrm{tha}^{-1}+\mathrm{K}$, no período de 13 a 32 meses pós-aplicação. A mineralização de P-orgânico principalmente oriundo do biossólido e a neutralização de sítios de fixação de $\mathrm{P}$ em óxidos de Fe e Al por ácidos orgânicos (Gonçalves \& Barros, 1999; Gonçalves et al. 2000) são causas prováveis e mais influentes desta rápida elevação dos teores de $\mathrm{P}$ - 
assimilável. A alta permeabilidade do solo (arenoso) e os índices pluviométricos observados no período (Figura 1) possibilitaram a lixiviação de $P$ da camada superficial do solo, migrando, possivelmente, na forma orgânica, esta em maior proporção (Novais \& Smith, 1999), e inorgânica (Bekunda et al., 1990).

A aplicação do biossólido levou, inicialmente, a um aumento do teor de S- $\mathrm{SO}_{4}{ }^{2-}$ no solo, observado aos seis meses pós-aplicação, devido à rápida mineralização de compostos sulfurados facilmente decomponíveis (Vaz, 2000). Posteriormente, o teor de $\mathrm{S}-\mathrm{SO}_{4}{ }^{2-}$ diminuiu acentuada e rapidamente (Figura 5). A lixiviação pode ter sido a causa mais influente deste declínio (Figura 1); também deve ter tido alta influência a absorção de $\mathrm{S}_{-} \mathrm{SO}_{4}{ }^{2-}$, devido à fase de rápido crescimento das árvores. Aos 32 meses pós-aplicação, há um aumento nos teores de $\mathrm{S}-\mathrm{SO}_{4}{ }^{2-}$, relativo à amostragem anterior, podendo estar associado

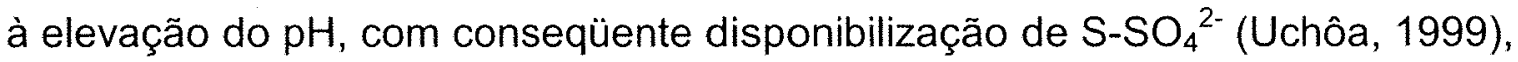
e ao efeito da mineralização da serrapilheira. Guedes (2000) reportou alta deposição de $S$ via serrapilheira, no mesmo povoamento e no vigésimo mês pós-aplicação do biossólido, em torno de 0,21 e $0,30 \mathrm{~kg} \mathrm{ha}^{-1}$ nos tratamentos com 20 e $40 \mathrm{t} \mathrm{ha}^{-1}$ de biossólido, respectivamente. Os teores de $\mathrm{S}_{-} \mathrm{SO}_{4}{ }^{2-}$ no solo e as doses de biossólido apresentaram relação linear aos 32 meses pósaplicação do biossólido, nas profundiades de 0-5 e 10-20 cm (Figura 5).

A elevada disponibilização do $\mathrm{Ca}$, passados 32 meses pós-aplicação do biossólido, parece ser a principal causa para o aumento do $\mathrm{pH}$ nesta idade (Figura 6). O teor variou de $2 \mathrm{mmol}_{\mathrm{c}} \mathrm{dm}^{-3}$ (inicial, camada $0-5 \mathrm{~cm}$ ) para $230 \mathrm{e}$ $300 \mathrm{mmol}_{\mathrm{c}} \mathrm{dm}^{-3}$ nos tratamentos 20 e $40 \mathrm{t} \mathrm{ha}^{-1}$ de biossólido, aos 32 meses. Comportamento semelhante foi observado em camadas subjacentes. Essa lenta solubilização e lixiviação de Ca são interessantes para o equilíbrio do sistema solo-planta, já que evitam a elevação brusca do $\mathrm{pH} e$, conseqüentemente, reduzem a possibilidade de competições sinérgicas e perdas por lixiviação de nutrientes deslocáveis por competição iônica do complexo sortivo do solo. Independente desse efeito, não foram constatadas deficiências de Ca nas árvores. Barros \& Novais (1996) salientam a baixa 
demanda de $\mathrm{Ca}$ pelo Eucalyptus grandis na fase inicial de crescimento. Esta demanda só se eleva na fase de intensa síntese de madeira, após o segundo ano de crescimento (Gonçalves et al., 2000).

As variações dos teores de $\mathrm{Mg}$ foram baixas, ao longo dos 32 meses pós-aplicação do biossólido, nas três profundidades (Figura 7). Elevação significativa do teor de $\mathrm{Mg}$ só foi observada aos 32 meses pós-aplicação do biossólido, na camada $0-5 \mathrm{~cm}$. Devido ao baixo teor de $\mathrm{Mg}$ no biossólido, o aporte de Mg no solo, via mineralização da serrapilheira, apresenta-se como uma das principais causas deste efeito. Como evidência desta afirmação, verificou-se que, na testemunha, o teor de $\mathrm{Mg}$ elevou-se de 1 para $2 \mathrm{mmol}_{\mathrm{c}}$ $\mathrm{dm}^{-3}$ de solo após 36 meses de plantio das árvores. Guedes (2000), para o vigésimo mês pós-aplicação do biossólido, estimou uma deposição de $\mathrm{Mg}$ em torno de $0,75 \mathrm{Kg} \mathrm{ha}^{-1}$ na testemunha.

De modo geral, o $\mathrm{K}$ apresentou elevação de seu teor nos primeiros meses pós-aplicação do biossólido, atingindo teores considerados adequados ao crescimento inicial do eucalipto (Vaz \& Gonçalves, 2002). Porém, a baixa concentração de $\mathrm{K}$ no biossólido e a complementação realizada com $\mathrm{K}$ em todos os tratamentos com biossólido, com finalidades de reposição e nivelação dos teores entre os tratamentos, deixam dúvidas quanto à contribuição do biossólido nas alterações de $K$ no solo (Figura 8). Aos treze meses pósaplicação, observou-se declínio de seus teores, em relação aos seis meses, possivelmente como conseqüência da absorção deste elemento pelas árvores e de sua lixiviação no solo, como conseqüência do elevado grau de saturação de $\mathrm{Ca}$, o qual potencializa a lixiviação de K (Sharpley \& Kamprath, 1988) (citado por Duriez, 1994). Segundo Chaves et al. (1995), com a elevação do pH, aumenta-se a adsorção dos cátions no solo, principalmente de $\mathrm{Ca}$ e $\mathrm{Mg} \mathrm{e}$, em menor grau, do K. Em altos teores de $\mathrm{Ca}$, como ocorreu neste experimento, presume-se que o $\mathrm{K}$ pudesse estar em situação mais lixiviável. Aos 32 meses, um pequeno aumento foi observado, provavelmente em decorrência da mineralização de serrapilheira. 
$\mathrm{Na}$ camada superficial, o teor de Al no solo decresceu ao longo do tempo, principalmente aos 32 meses pós-aplicação do biossólido, e variou entre os tratamentos, sendo menor nos tratamentos influenciados pela adição do biossólido $\left(40,20\right.$ e $10 \mathrm{t} \mathrm{ha}^{-1}+\mathrm{K}$, nesta ordem) e maior nos tratamentos sob efeito da adubação mineral e testemunha (Figura 9). A este comportamento, pode-se associar a complexação do Al pela MO (Miyazawa, 1992) e ao processo de neutralização do $\mathrm{pH}$, conseqüência da solubilização crescente do Ca adicionado via biossólido, precipitando e reduzindo o efeito tóxico do Al do solo (Defelipo \& Braga, 1983). Na testemunha, os teores de Al apresentaram evolução oposta, com aumento a partir dos 13 meses. Nas demais camadas estudadas, cujo processo de lixiviação tem importante atuação, o tempo requerido para a neutralização do Al foi maior, porém sendo percebido já aos 32 meses da aplicação. Comparando-se os tratamentos neste mesmo periodo, observou-se uma relação quadrática entre doses de biossólido e a neutralização do Al em todas as camadas estudadas. 


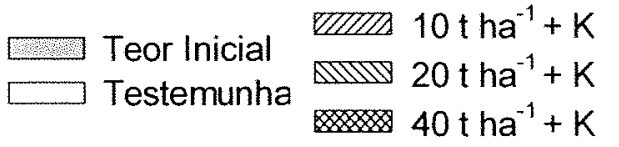

Biossólido $+K$

Adubação Mineral

$10 t h a^{-1}+K+P$
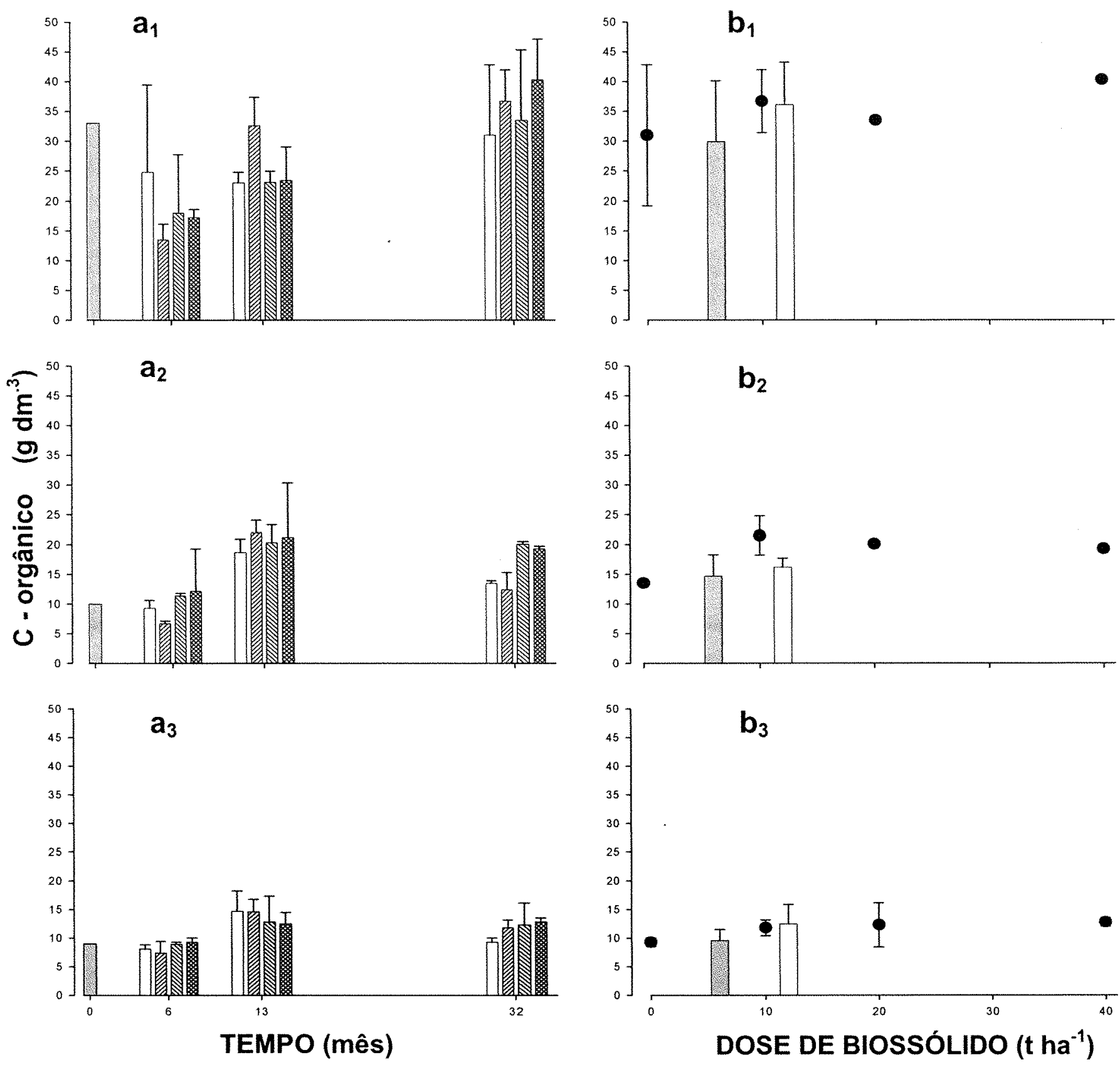

Figura 2 - Teores de carbono orgânico (média \pm intervalo de confiança) a 0, 6, 13 e 32 meses pósaplicação do biossólido (doses 0, 10, 20 e $40 \mathrm{tha}^{-1}+\mathrm{K}$ ), nas profundidades 0-5 $\left(\mathrm{a}_{1}\right), 5-10\left(\mathrm{a}_{2}\right)$ e 10-20 $\left(\mathrm{a}_{3}\right) \mathrm{cm}$ e comparação entre tratamentos, aos 32 meses pós-aplicação do biossólido, nas profundidades $0-5\left(b_{1}\right), 5-10\left(b_{2}\right)$ e $10-20\left(b_{3}\right) \mathrm{cm}$. 

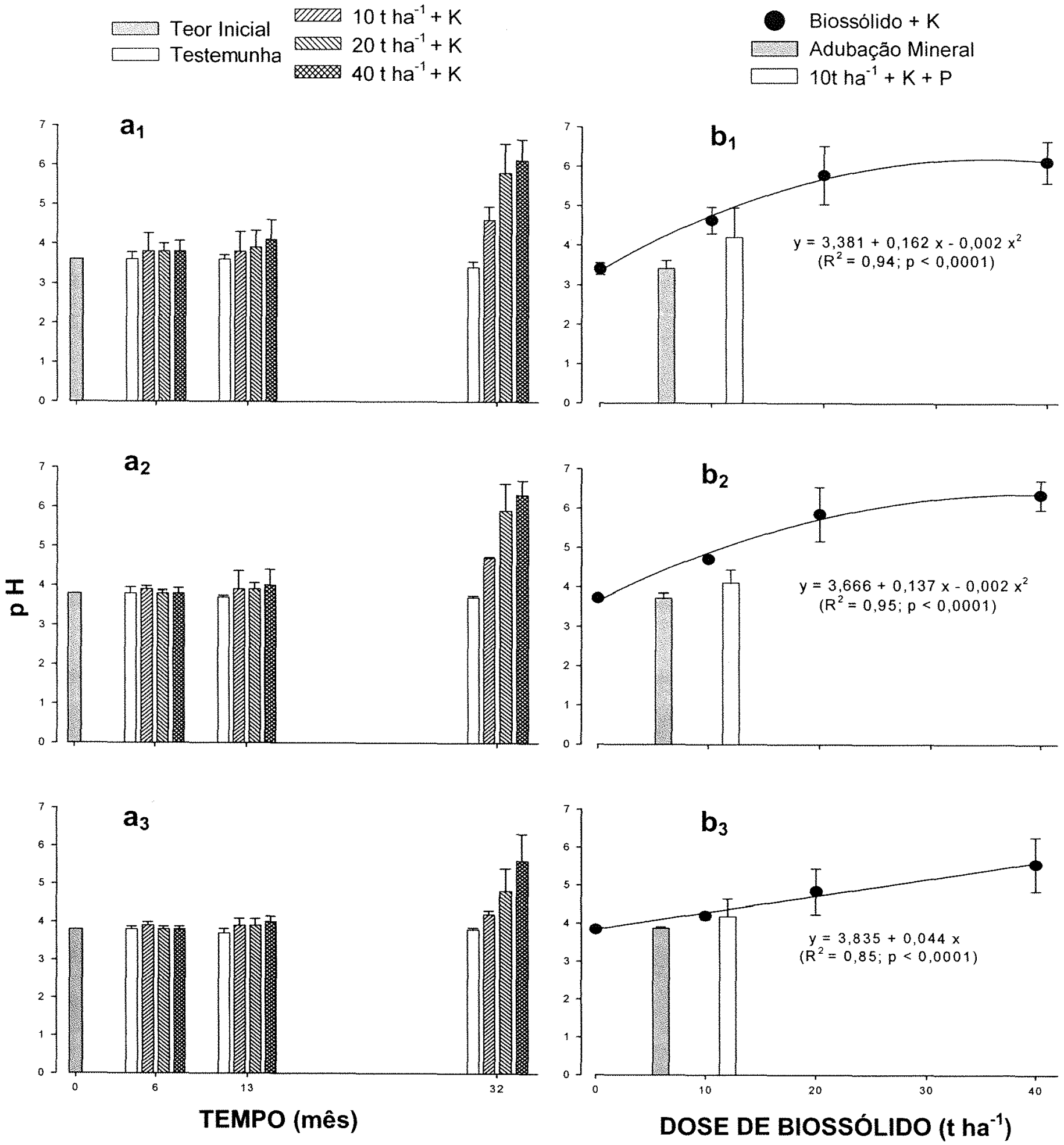

Figura 3 - Valores de pH (média \pm intevalo de confrança) aos 0, 6, 13 e 32 meses pós-aplicação do biossólido (doses $0,10,20$ e $40 \mathrm{t} \mathrm{ha}^{-1}+\mathrm{K}$ ), nas profundidades $0-5\left(\mathrm{a}_{1}\right), 5-10\left(\mathrm{a}_{2}\right)$ e $10-20\left(\mathrm{a}_{3}\right) \mathrm{cm}$ e comparação entre tratamentos, aos 32 meses pós-aplicação do biossólido, nas profundidades 0-5 $\left(b_{1}\right), 5-10\left(b_{2}\right)$ e $10-20\left(b_{3}\right) \mathrm{cm}$. 

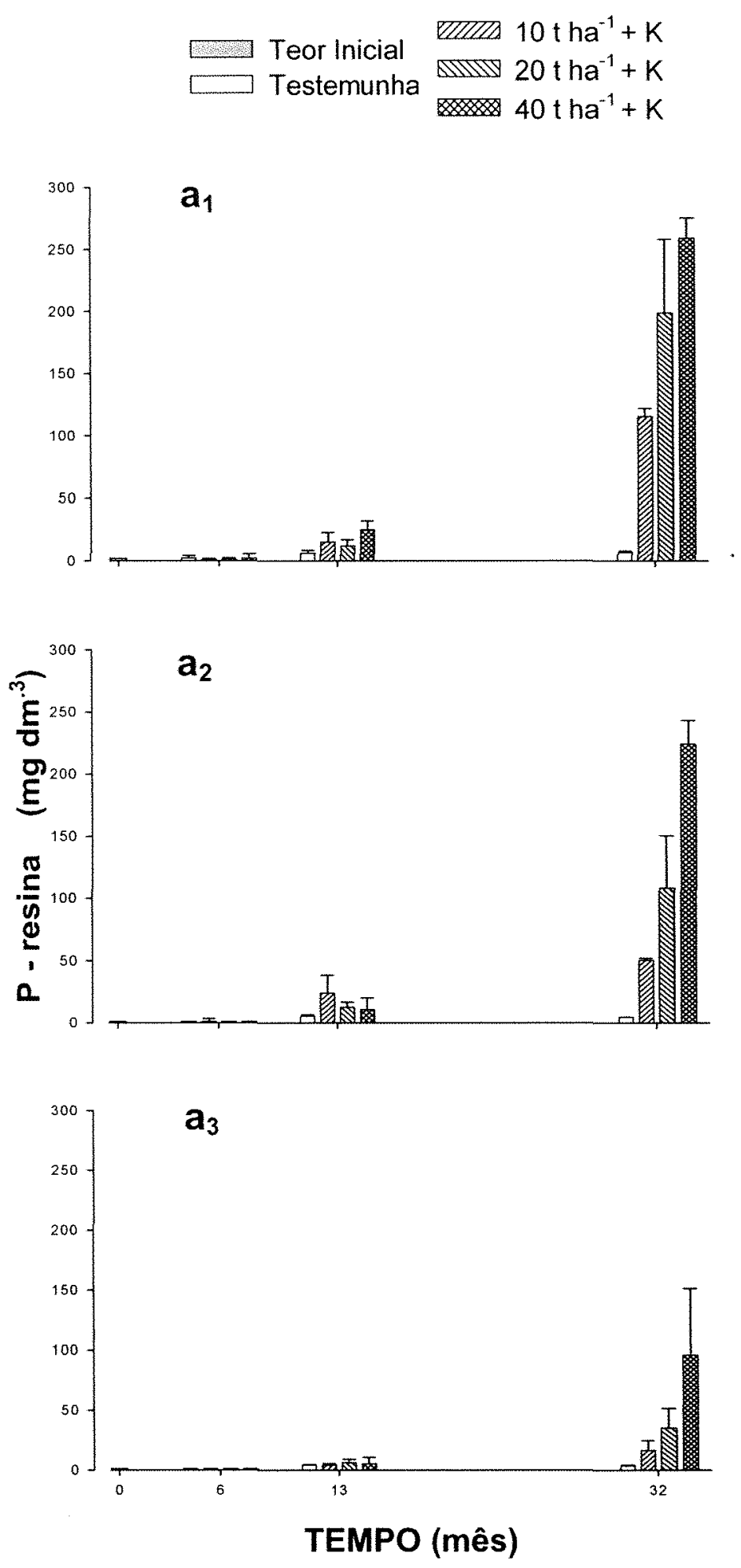
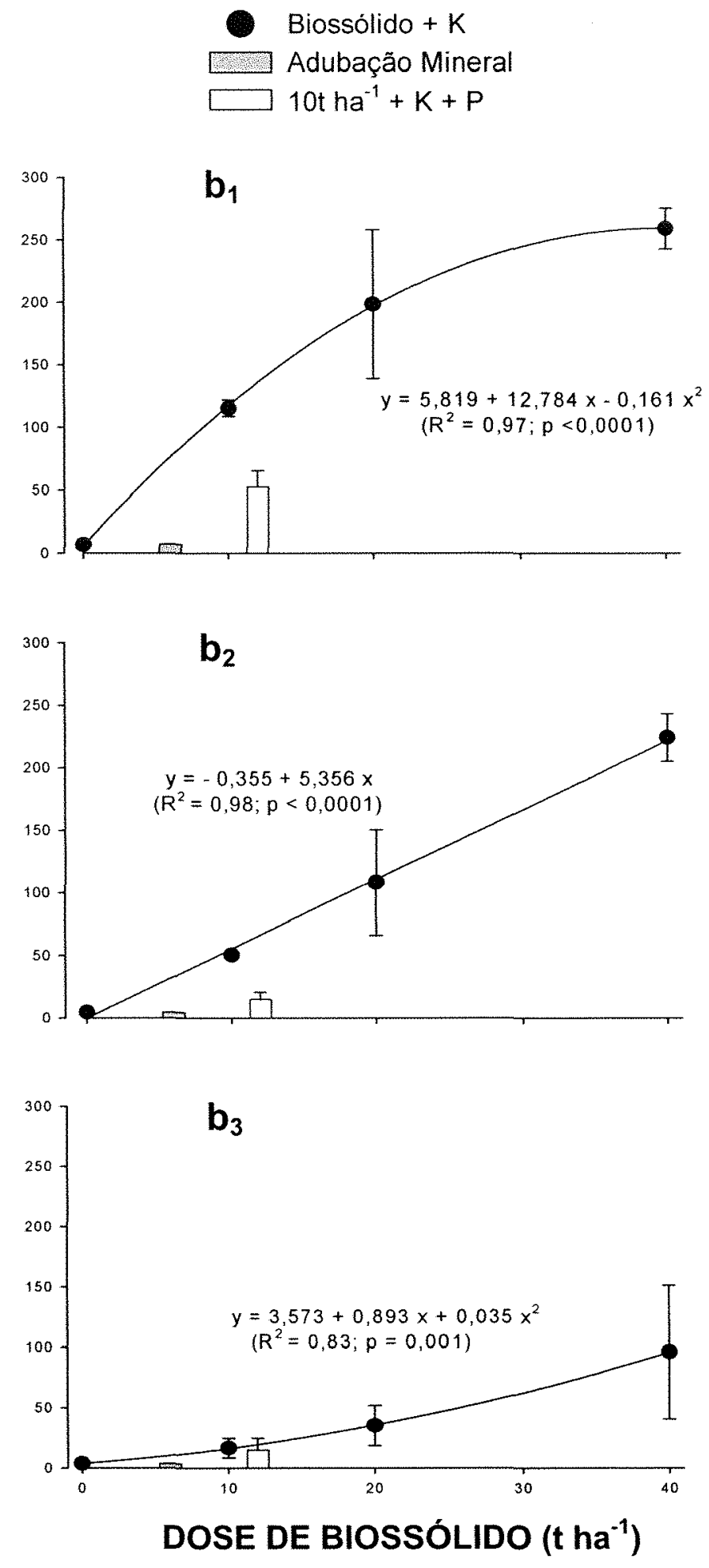

Figura 4 - Teores de fósforo (média \pm intervalo de confiança) aos 0, 6, 13 e 32 meses pós-aplicação do biossólido (doses $0,10,20$ e $40 \mathrm{t} \mathrm{ha}^{-1}+\mathrm{K}$ ), nas profundidades $0-5\left(\mathrm{a}_{1}\right), 5-10\left(\mathrm{a}_{2}\right)$ e $10-20\left(\mathrm{a}_{3}\right) \mathrm{cm}$ e comparação entre tratamentos, aos 32 meses pós-aplicação do biossólido, nas profundidades $0-5\left(b_{1}\right), 5-10\left(b_{2}\right)$ e $10-20\left(b_{3}\right) \mathrm{cm}$. 

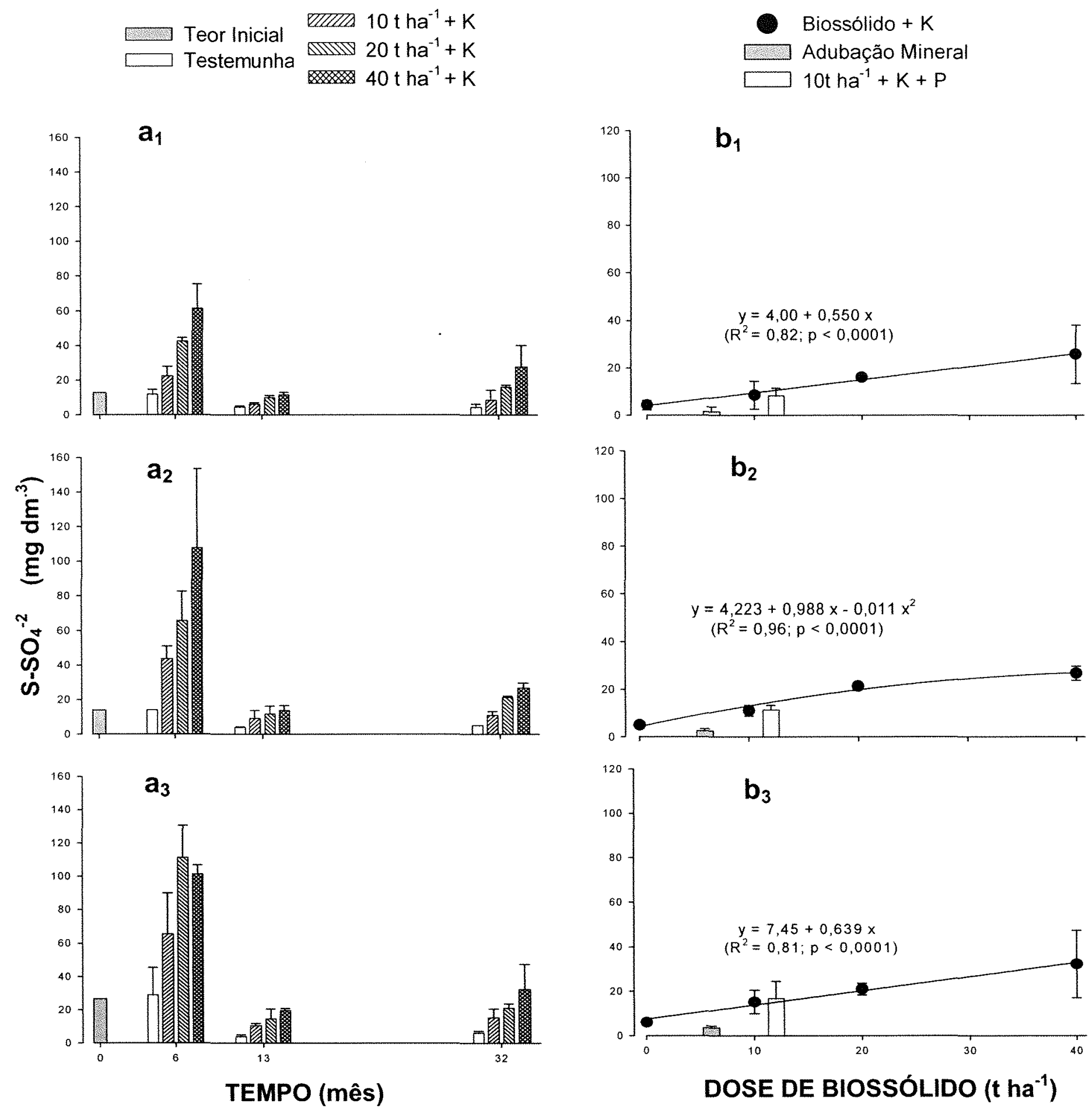

Figura 5 - Teores de enxofre (média \pm intervalo de confiança) aos 0, 6, 13 e 32 meses pós-aplicação do biossólido (doses 0, 10, 20 e $40 \mathrm{t} \mathrm{ha}^{-1}+\mathrm{K}$ ), nas profundidades $0-5\left(\mathrm{a}_{1}\right), 5-10\left(\mathrm{a}_{2}\right)$ e $10-20\left(\mathrm{a}_{3}\right) \mathrm{cm}$ e comparação entre tratamentos, aos 32 meses pós-aplicação do biossólido, nas profundidades $0-5\left(b_{1}\right), 5-10\left(b_{2}\right)$ e $10-20\left(b_{3}\right) \mathrm{cm}$. 

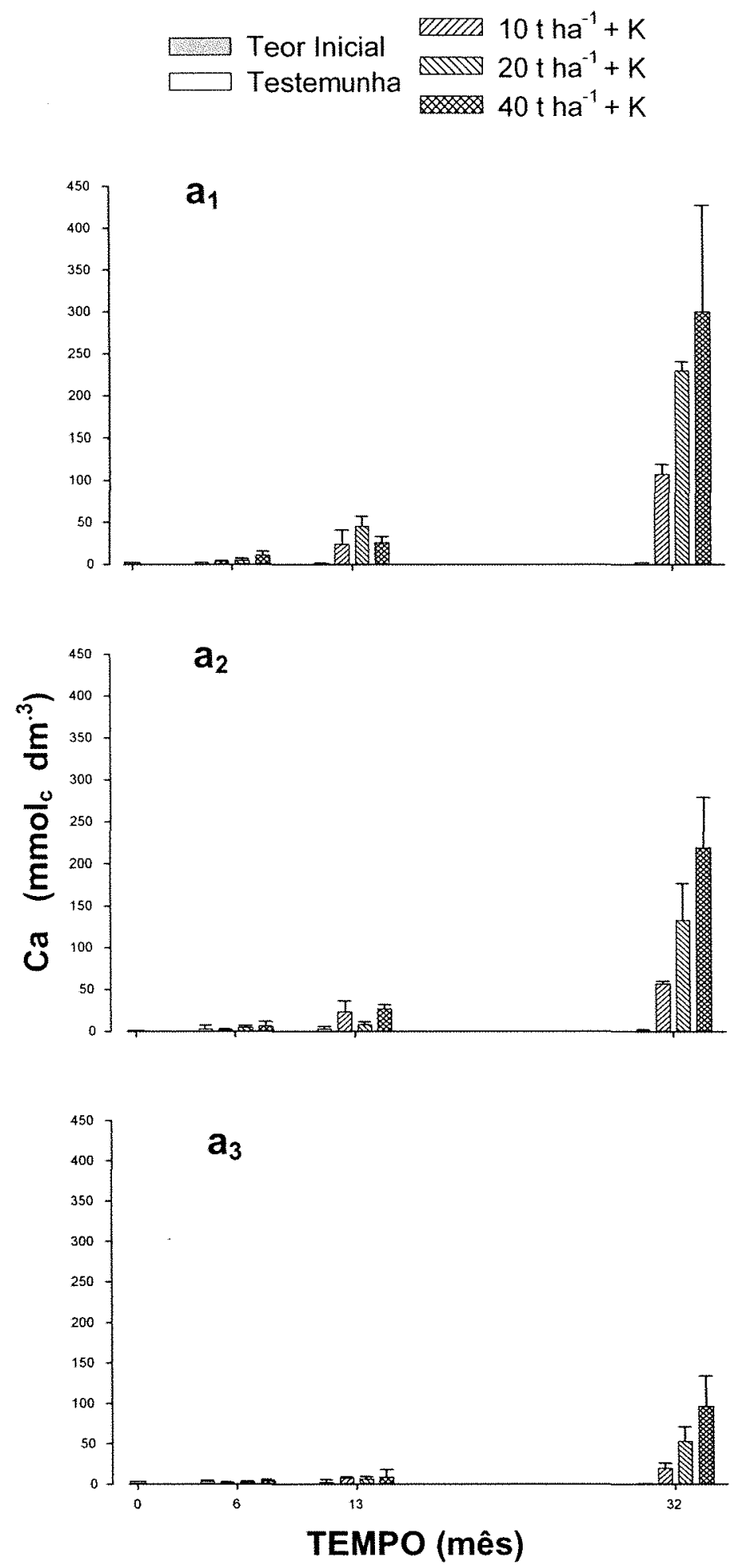
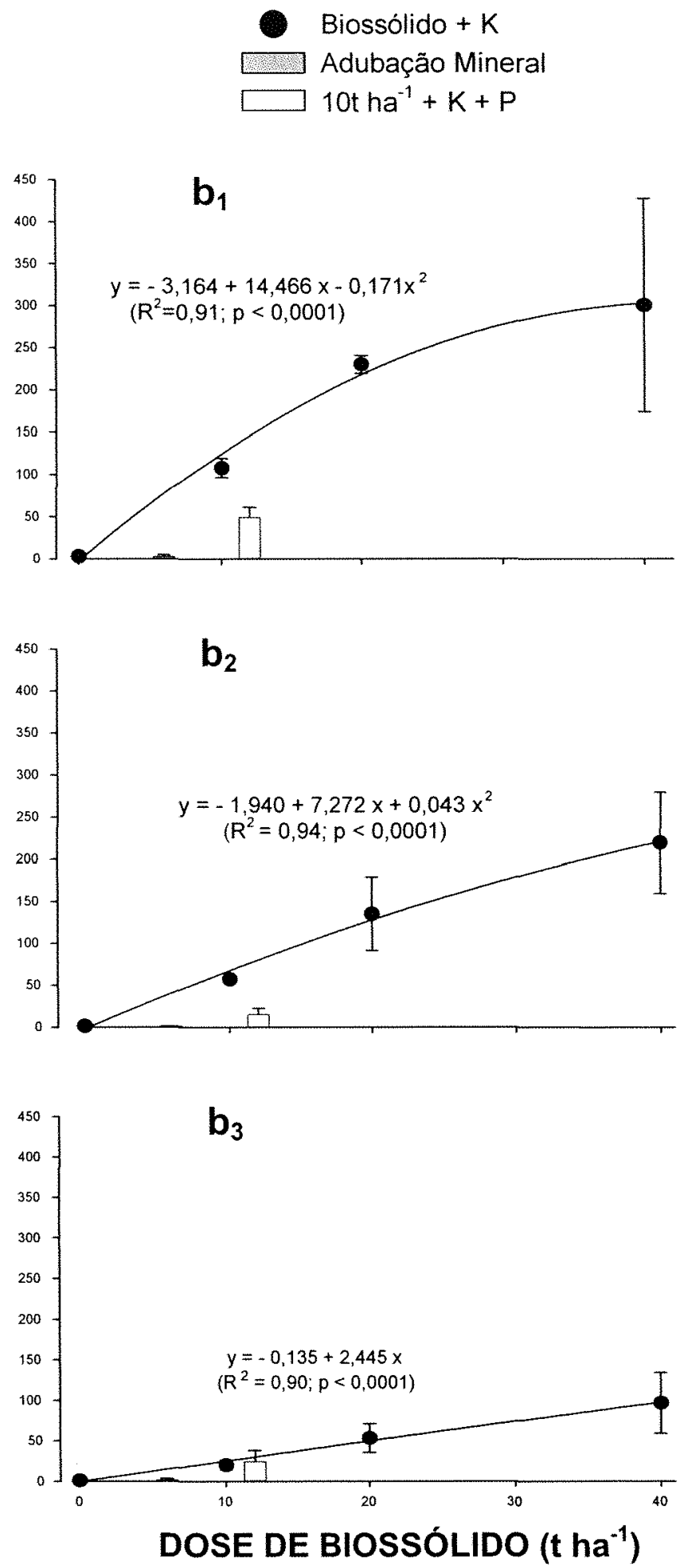

Figura 6 - Teores de cálcio (média \pm intervalo de confiança) aos 0, 6, 13 e 32 meses pós-aplicação do biossólido (doses 0, 10, 20 e $40 \mathrm{t} \mathrm{ha}^{-1}+\mathrm{K}$ ), nas profundidades $0-5\left(\mathrm{a}_{1}\right), 5-10\left(\mathrm{a}_{2}\right)$ e $10-20\left(\mathrm{a}_{3}\right) \mathrm{cm}$ e comparação entre tratamentos, aos 32 meses pós-aplicação do biossólido, nas profundidades $0-5\left(b_{1}\right), 5-10\left(b_{2}\right)$ e $10-20\left(b_{3}\right) \mathrm{cm}$. 


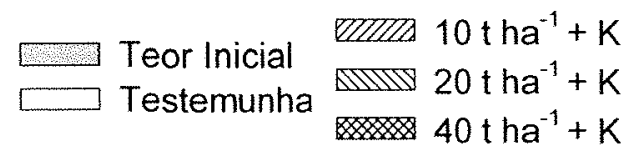

$a_{1}$
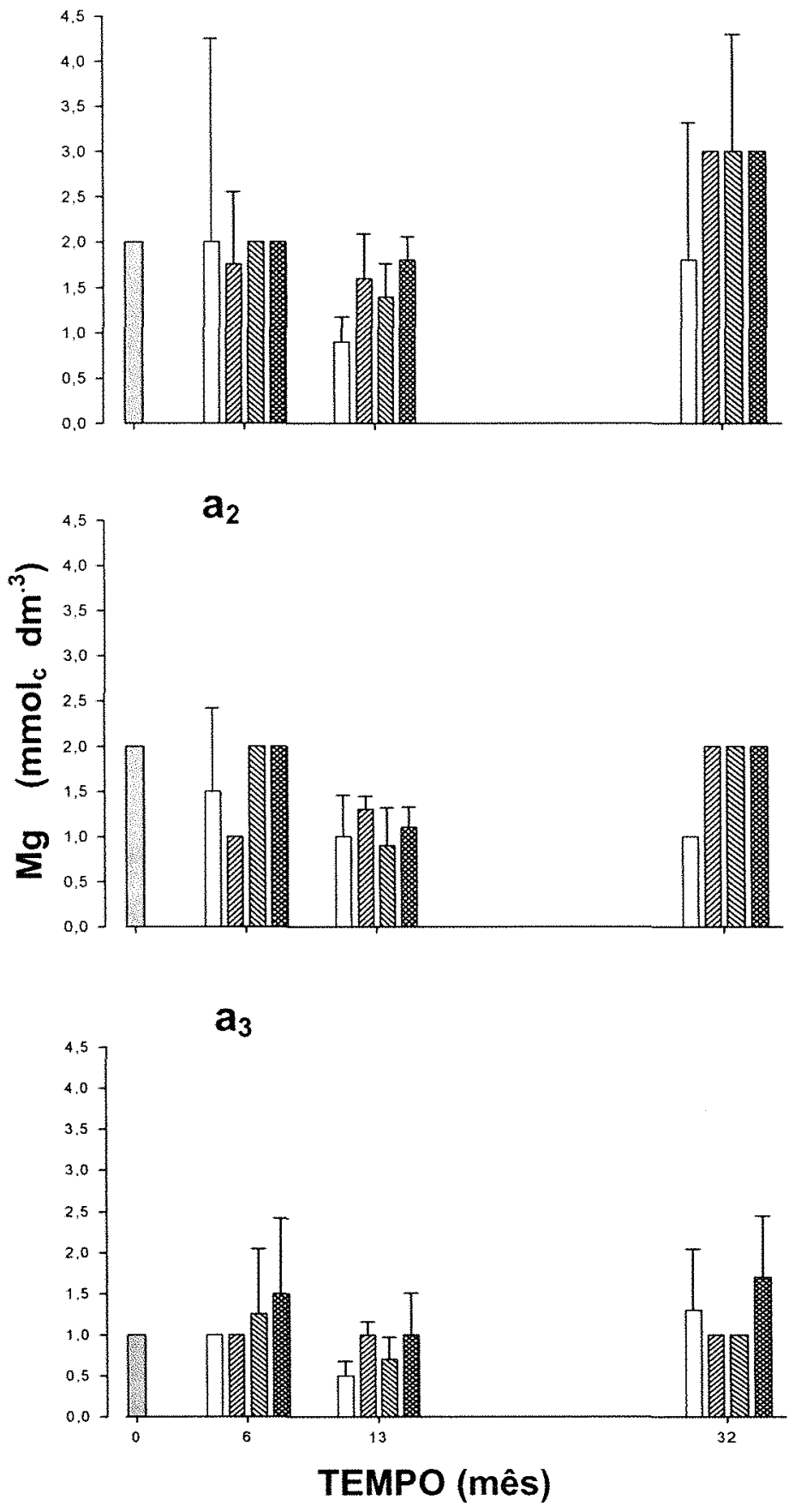

Biossólido $+K$ Adubação Mineral $10 \mathrm{tha}^{-1}+\mathrm{K}+\mathrm{P}$

$\mathbf{b}_{1}$

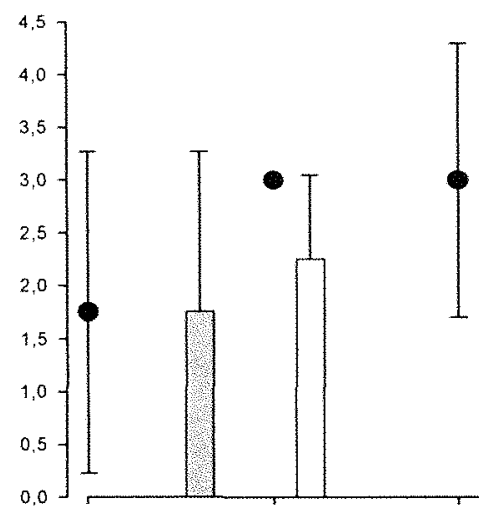

$b_{2}$
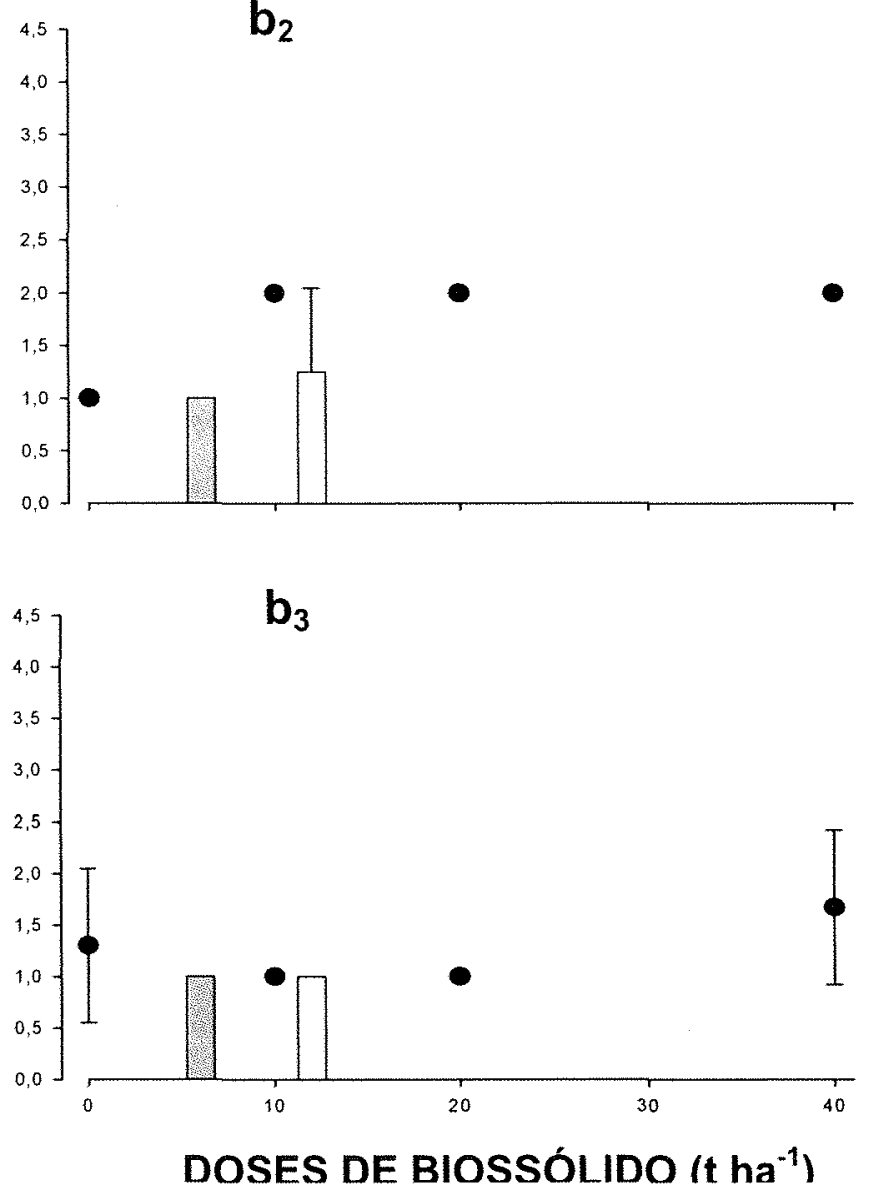

Figura 7 - Teores de magnésio (média \pm intervalo de confiança) aos $0,6,13$ e 32 meses pós-aplicação do biossólido (doses 0, 10, 20 e $40 \mathrm{t} \mathrm{ha}^{-1}+\mathrm{K}$ ), nas profundidades 0-5 $\left(\mathrm{a}_{1}\right), 5-10\left(\mathrm{a}_{2}\right)$ e 10-20 $\left(\mathrm{a}_{3}\right) \mathrm{cm}$ e comparação entre tratamentos, aos 32 meses pós-aplicação do biossólido, nas profundidades 0-5 $\left(b_{1}\right), 5-10\left(b_{2}\right)$ e $10-20\left(b_{3}\right) \mathrm{cm}$. 

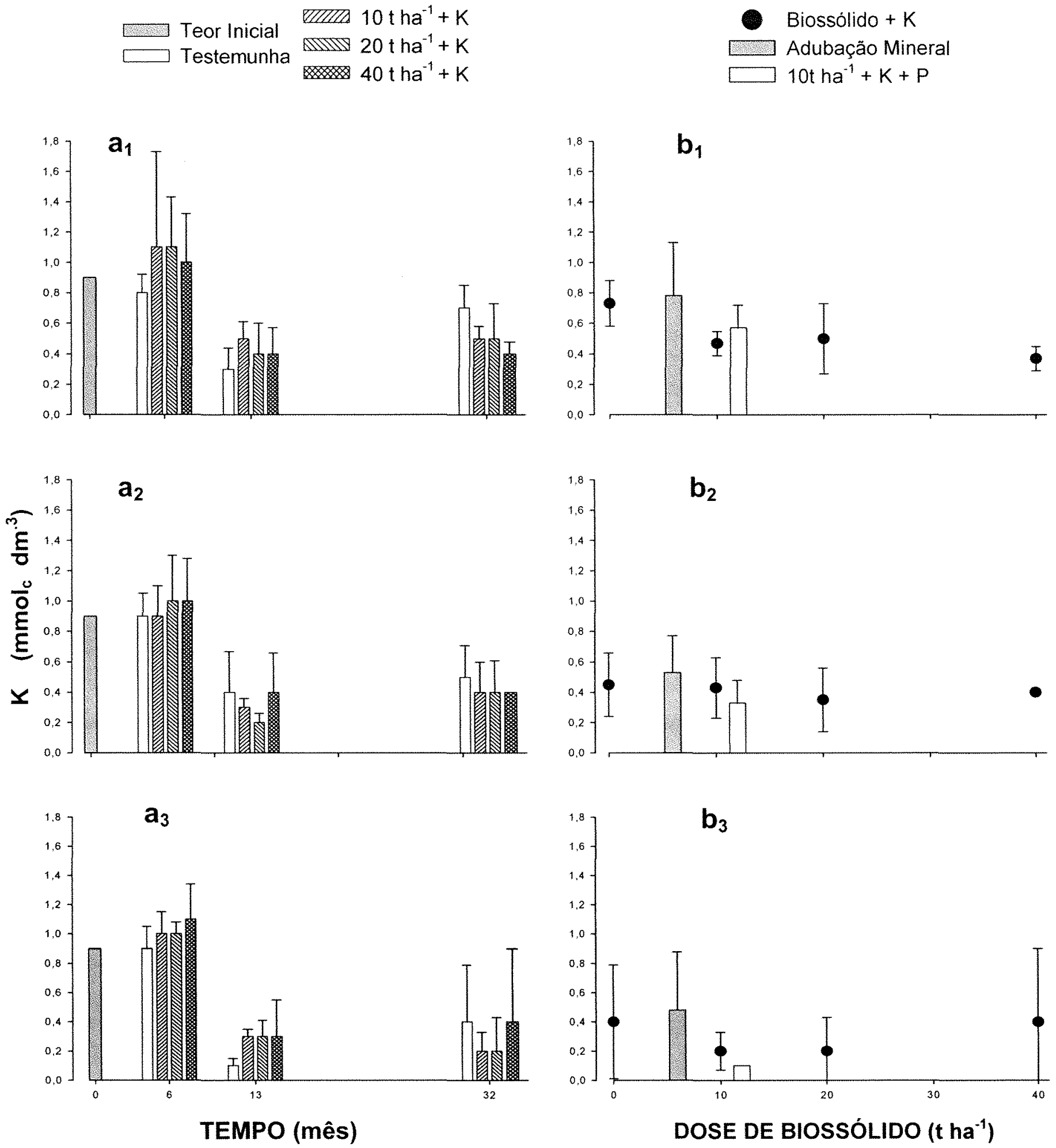

Figura 8 - Teores de potássio (média \pm intervalo de confiança) aos 0, 6, 13 e 32 meses pós-aplicação do biossólido (doses 0, 10, 20 e $40 \mathrm{tha}+\mathrm{K}$ ), nas profundidades 0-5 $\left(\mathrm{a}_{1}\right), 5-10\left(\mathrm{a}_{2}\right)$ e $10-20\left(\mathrm{a}_{3}\right) \mathrm{cm}$ e comparação entre tratamentos, aos 32 meses pós-aplicação do biossólido, nas profundidades $0-5\left(b_{1}\right), 5-10\left(b_{2}\right)$ e $10-20\left(b_{3}\right) \mathrm{cm}$. 

Teor Inicial
Testemunha

\begin{abstract}
पemes $10 \mathrm{tha}^{-1}+\mathrm{K}$
$20 \mathrm{tha}^{-1}+\mathrm{K}$

$40 \mathrm{tha}^{-1}+\mathrm{K}$
\end{abstract}
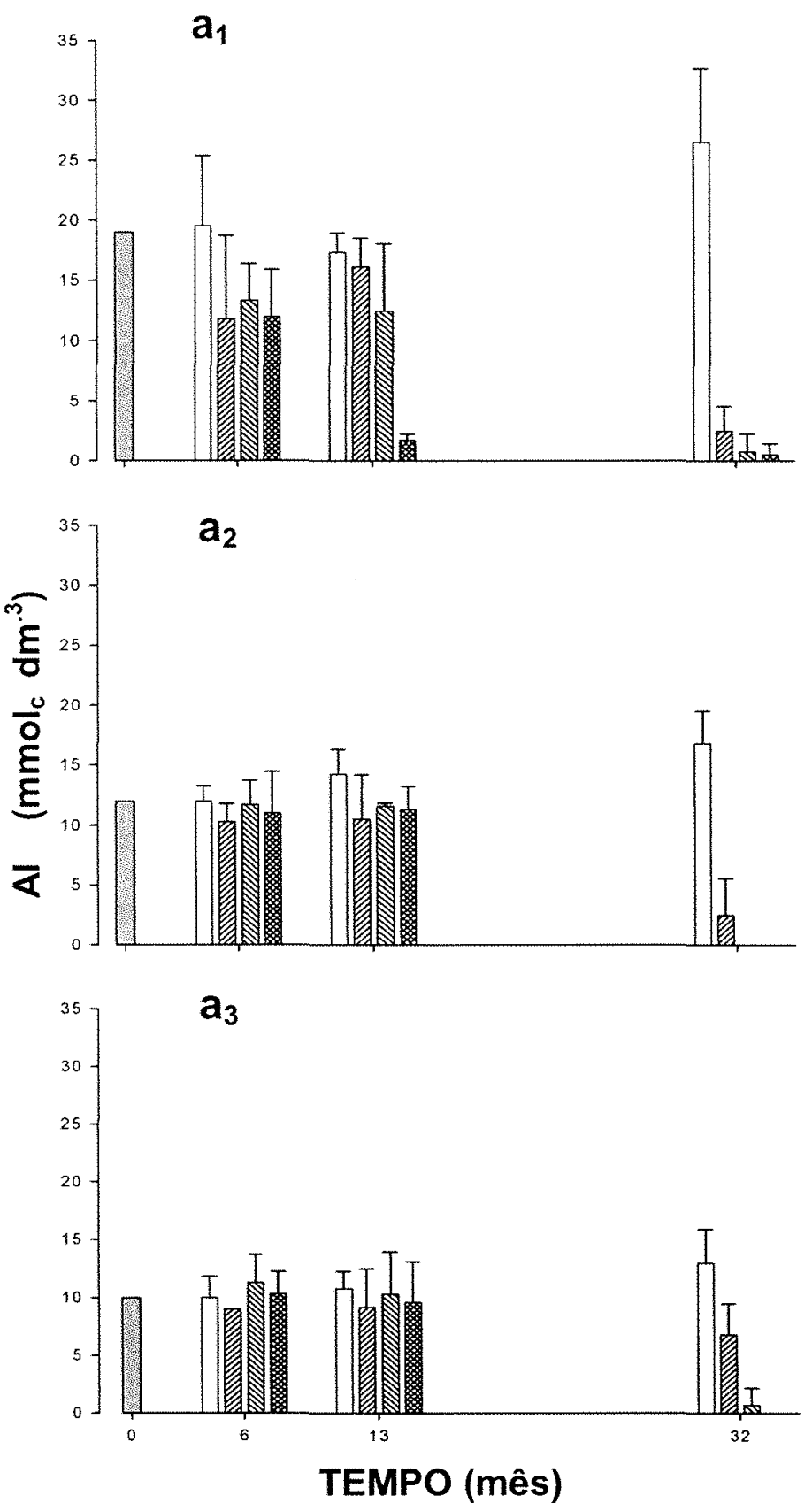

- Biossólido $+K$

Adubação Mineral

$10 \mathrm{tha}^{-1}+K+P$
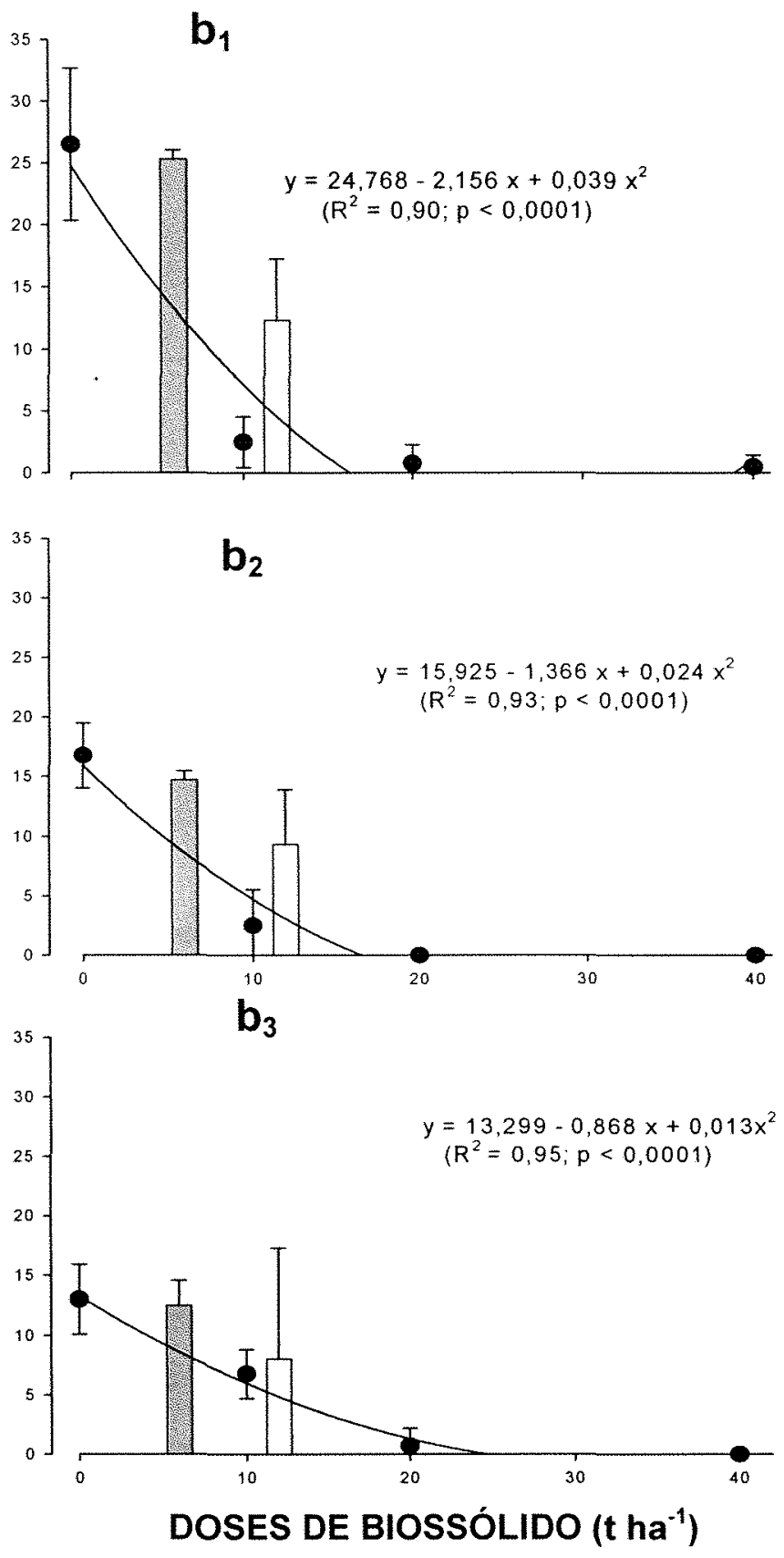

Figura 9 - Teores de alumínio (média \pm intervalo de confiança) aos 0, 6, 13 e 32 meses pós-aplicação do biossólido (doses 0, 10, 20 e $40 \mathrm{t} \mathrm{ha}^{-1}+\mathrm{K}$ ), nas profundidades 0-5 $\left(\mathrm{a}_{1}\right), 5-10\left(\mathrm{a}_{2}\right)$ e 10-20 $\left(\mathrm{a}_{3}\right) \mathrm{cm}$ e comparação entre tratamentos, aos 32 meses pós-aplicação do biossólido, nas profundidades $0-5\left(b_{1}\right), 5-10\left(b_{2}\right)$ e $10-20\left(b_{3}\right) \mathrm{cm}$. 


\subsection{Nutrição Mineral}

Os teores foliares de macro e micronutrientes ficaram dentro da faixa de suficiência em todos os tratamentos que receberam biossólido, conforme valores de referência apresentados por Gonçalves et al. (1996) e Silveira et al. (2000) (Figuras 10 e 11).

Houve acentuado aumento dos teores de $\mathrm{N}$ foliar, predominantemente atribuído à mineralização da $\mathrm{MO}$ do biossólido (Figura 10), a despeito de não ter sido encontrada correlação significativa entre teor de $\mathrm{N}$ e dose de biossólido aplicada. A maior absorção e assimilação de $\mathrm{N}$ nos tratamentos que receberam biossólido é aceita como uma das principais causas de resposta em crescimento das árvores, em função do baixo teor de $\mathrm{MO}$ e do grau de degradação química do solo (Vaz, 2000), ocasionada pela grande extração de nutrientes via colheita de madeira de eucalipto (mais de 30 anos de cultivos sucessivos com plantações monoespecíficas de eucalipto) e lixiviação. Até o fechamento da copa (aproximadamente 24 meses), a demanda de $\mathrm{N}$ é elevada, devido ao estádio de rápida formação de copas (Gonçalves et al., 2000). Aos 24 e 36 meses de idade, os teores foliares de $\mathrm{N}$ foram menores que os iniciais, nos tratamentos com biossólido, talvez devido à uma ou mais das seguintes causas: a) diluição das quantidades de $\mathrm{N}$ numa maior biomassa foliar, ou seja, a assimilação de $\mathrm{N}$ não manteve-se proporcional à sintese de folhas ao longo do tempo, devido a uma velocidade de crescimento foliar maior do que a absorção de $\mathrm{N}$ ou a disponibilidade de $\mathrm{N}$ no solo caiu com o tempo (causa mais provável); b) diminuição da demanda de $\mathrm{N}$ pela árvore, devido ao fechamento de copas e à queda no metabolismo foliar, ocasionada por maior intra e intercompetição foliar por luz e água, sobretudo nas porções de copas mais velhas; e c) retranslocação interna de $\mathrm{N}$.

$\mathrm{O}$ aumento da disponibilidade de $\mathrm{P}$ verificada nos últimos meses (Figura 4) não resultou em aumento de teores de $P$ no tecido foliar (Figura 10); os teores de $\mathrm{P}$ apresentaram baixa variação ao longo do tempo e sem correlação 
com as doses aplicadas de biossólido. No tratamento que recebeu adubação mineral, o teor de $P$ foi bem mais elevado do que os demais tratamentos, aos 12 meses de idade (Figura 10), devido à rápida assimilação do $P$ solúvel aplicado. Com o passar do tempo, o teor de $\mathrm{P}$ neste tratamento caiu, devido ao efeito de diluição foliar e à redução da disponibilidade de $P$. Nos tratamentos cujas doses aplicadas foram de 15, 20 e $40 \mathrm{tha}^{-1}+\mathrm{K}$ e $10 \mathrm{t} \mathrm{ha} \mathrm{h}^{-1}+\mathrm{K}+\mathrm{P}$, este efeito de aumento do teor foliar foi verificado aos 24 meses, seguido de declínio aos 36 meses de idade. A não resposta ao aumento do $P$ disponível no solo, nesta idade, pode estar mascarada pelo pouco tempo decorrido entre a maior taxa de disponibilização do $P$ e a amostragem realizada e pelo retranslocamento de $\mathrm{P}$ das folhas para outras partes, como a casca, em atual estágio de maior desenvolvimento. Segundo Bellote \& Silva (2000), a alocação de $\mathrm{P}$ para a casca pode atingir $90 \%$ do $\mathrm{P}$ das folhas. Outra possibilidade para a não-resposta se deve à baixa absorção de $P$ nesta fase de desenvolvimento. Segundo Barros et al. (1982), os níveis críticos de P para o crescimento inicial de mudas de eucalipto são elevados, demonstrando que, no estádio muito jovem, o eucalipto se mostra pouco efetivo na sua absorção. Após o fechamento das copas, caracterizada entre outras, pela maior taxa de acúmulo de nutrientes na biomassa vegetal, maior ciclagem e maior eficiência no uso de nutrientes (Gonçalves et al., 2000), o povoamento se mostra mais independente de fontes extras de nutrientes, diminuindo a resposta ao biossólido.

Os teores foliares de $\mathrm{K}$ e $\mathrm{Mg}$ não apresentaram diferenças entre os tratamentos com biossólido, ao longo do tempo (Figura 10). A diminuição dos teores de $\mathrm{K}$ até os 32 meses de idade, para todos tratamentos com biossólido, predominantemente, deve ser efeito da retranslocação interna desse nutriente ou então devido a um efeito antagônico do $\mathrm{Ca}$ sobre $\mathrm{o} \mathrm{K}$ no processo de absorção, fato também observado por Gonçalves et al. (1986), para solos com estreita relação Ca/Mg. Segundo Vaz \& Gonçalves (2002), o maior teor de K na testemunha (aos 12 meses de idade) em relação aos demais tratamentos se deve ao efeito concentração nesse tratamento, causado pelo menor 
crescimento da área foliar. Interpretação semelhante pode ser dada aos resultados obtidos para o $\mathrm{Mg}$.

A elevada disponibilidade de Ca ocorrida nos últimos meses não afetou o teor foliar aos 32 meses de idade, a qual permaneceu inalterada em relação à amostra anterior (Figura 10). Uma possível elevação na taxa de absorção de $\mathrm{Ca}$, não refletida nos teores foliares, pode ser atribuída, em parte, à alta assimilação deste nutriente na síntese de casca e de lenho (Gonçalves et al., 2000), assim como por efeito de diluição, também observado por Bellote \& Ferreira (1995), para povoamentos de três anos, no Estado de São Paulo.

$\mathrm{O}$ aumento do teor foliar de $\mathrm{S}$ foi evidente apenas na idade de 24 meses (Figura 10). Após esta idade, uma possivel diminuição na absorção deste nutriente, o efeito diluição e as perdas por lixiviação são potenciais causas para o declínio dos teores foliares deste nutriente. Contudo, o E. grandis se apresenta pouco responsivo ao $S$ (Furtini-Neto et al., 1988), não havendo indícios de influência negativa dos baixos teores encontrados no experimento.

Em relação aos micronutrientes estudados (Figura 11), apenas o $\mathrm{Mn}$ mostrou sensivel relação com as doses de biossólido aplicadas, diminuindo seu teor foliar com o aumento das doses aplicadas. O Fe, Cu e Zn, aos 32 meses, apresentaram menores teores que nos meses anteriores, não apresentando diferenças entre os tratamentos. Vaz (2000) chama a atenção para o menor teor foliar de $\mathrm{Zn}$, aos 12 meses de idade, no tratamento que recebeu adubação mineral, podendo estar implícito o antagonismo entre este nutriente e o $\mathrm{P}$ aplicado na fertilização de base. Duas causas podem estar relacionadas aos baixos teores de micronutrientes aos 32 meses pós-aplicação: a) o efeito diluição, decorrente do crescimento da biomassa e da taxa de absorção igual ou menor que em épocas anteriores; e b) a elevação do pH, levando a uma indisponibilidade destes micronutrientes. 
-12 meses
- 24 meses
$\nabla \quad 36$ meses
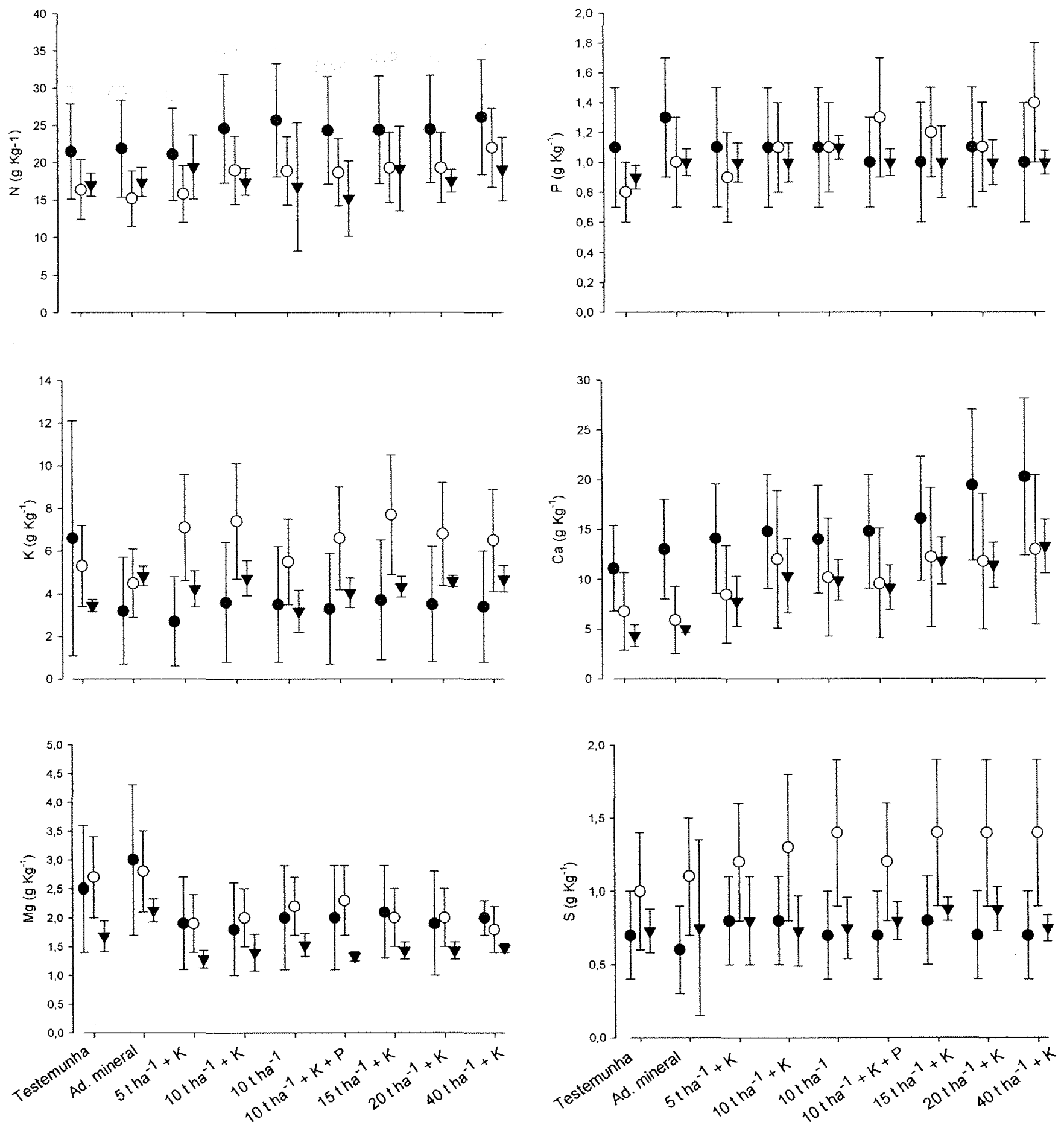

TRATAMENTO

Figura 10 - Concentração foliar de macronutrientes (média \pm intervalo de confiança) aos 12, 24 e 36 meses de idade das plantas, 8,20 e 32 meses pós-aplicação do biossólido, respectivamente, nos diferentes tratamentos. 
- 12 meses

- 24 meses

V 36 meses
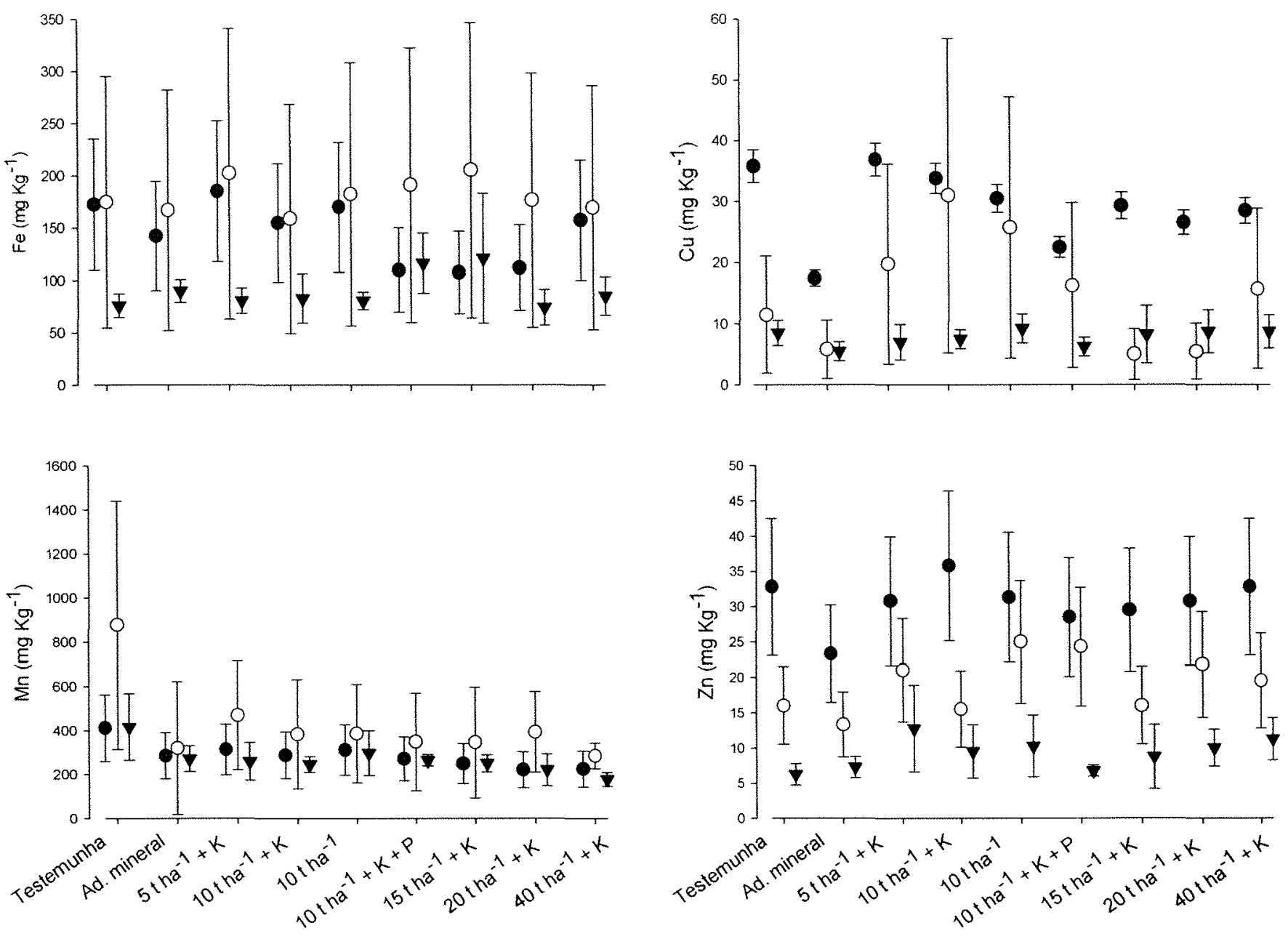

TRATAMENTO

Figura 11 - Concentração foliar de micronutrientes (média \pm intervalo de confiança) aos 12, 24 e 36 meses de idade das plantas, 8,20 e 32 meses pós-aplicação do biossólido, respectivamente, nos diferentes tratamentos. 


\subsection{Produção de madeira}

A elevação das doses de biossólido, de 0 a $40 \mathrm{t} \mathrm{ha}^{-1}$, resultou numa resposta quadrática em termos de produtividade de madeira sem casca, aos 12 , 24 e 36 meses de idade (Figura 12). A aplicação do biossólido tendeu a elevar a produtividade acima da obtida com adubação mineral para a área em estudo, mais evidente aos 36 meses. A produção média deste tratamento foi de $35,9 \mathrm{t}$ ha $^{-1}$, ou seja, $3,4 \%, 7,1 \%, 18,0 \%, 5,3 \%$ e $29,0 \%$ menor que a produção nos tratamentos com 5, 10, 15, 20 e $40 \mathrm{t} \mathrm{ha}^{-1}$ de biossólido $+\mathrm{K}$, respectivamente. A suplementação da dose de $10 \mathrm{t} \mathrm{ha}^{-1}$ com $\mathrm{K}$ e $\mathrm{P}$ levou a uma produção de madeira equivalente à dose de $40 \mathrm{tha}^{-1}+\mathrm{K}$. Entretanto, a definição da dose de biossólido que deve ser aplicada, além de considerar aspectos econômicos, deve considerar o efeito residual. O acompanhamento contínuo da produção de madeira e das mudanças de fertilidade do solo deve trazer maior clareza quanto ao potencial de cada dose em fornecer nutrição adequada às árvores nas próximas rotações de cultivo.

Dos 12 aos 24 meses de idade, o aumento na biomassa de madeira para o tratamento sob efeito da adubação mineral foi de $0,77 \mathrm{t} \mathrm{ha}^{-1} \mathrm{mês}^{-1}$ (aumento total de $46,5 \%$ ) e, dos 24 aos 36 meses de idade, de 0,57 t ha $^{-1}$ mês $^{-1}$ (aumento total de 23,8\%). O mesmo comportamento ocorreu nos tratamentos 10 e $15 \mathrm{t}$ $\mathrm{ha}^{-1}$, o primeiro sem suplementação de K. Esta diminuição está associada à menor disponibilidade de nutrientes com o tempo e à maior competição entre plantas por luz, água e nutrientes (Figuras 2, 4, 5, 6 e 7), refletida nos teores foliares de nutrientes (Figuras 10 e 11).

Nos tratamentos com 5, 10, 20 e $40 \mathrm{tha}^{-1}$ de biossólido $+\mathrm{K}$ foi observado aumento de produtividade do primeiro periodo (12-24 meses) para o segundo (24-36 meses), sendo, neste último, superior a 1,00 $\mathrm{tha}^{-1} \mathrm{mês}^{-1}$. As doses de 10 e $40 \mathrm{t} \mathrm{ha}^{-1}$ de biossólido $+\mathrm{K}$ apresentaram produtividades médias semelhantes aos 36 meses $\left(1,29 \mathrm{t} \mathrm{ha}^{-1} \mathrm{mês}^{-1}\right)$, embora a maior dose tenha produzido mais madeira. 
- 12 meses

O 24 meses

$\checkmark 36$ meses

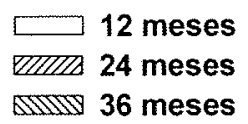

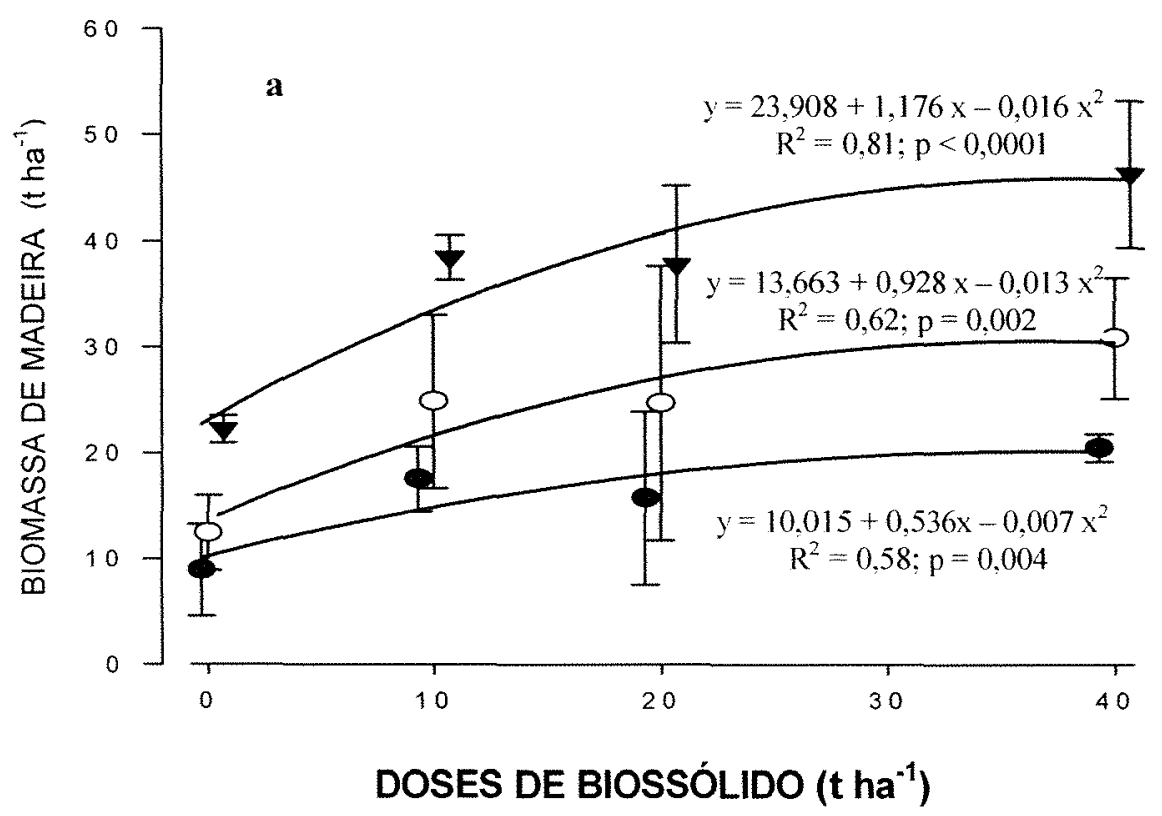

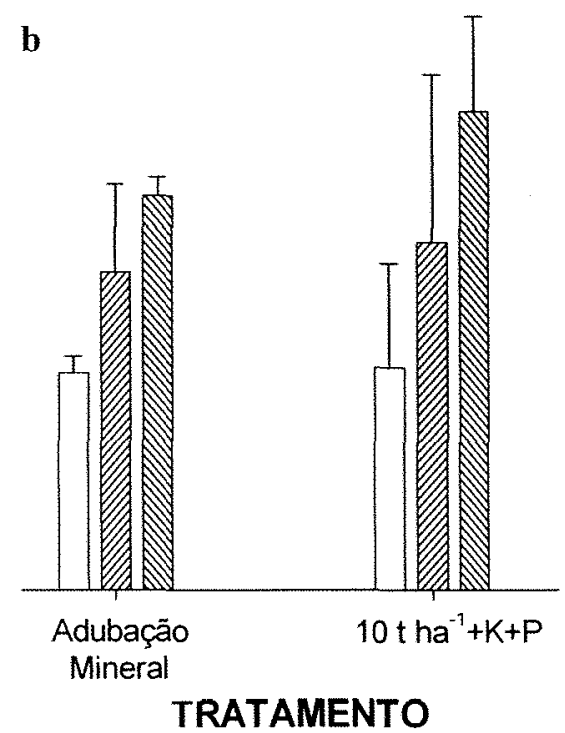

Figura 12 - Biomassa seca de madeira (média \pm intervalo de confiança) sem casca em resposta às doses crescentes de biossólido, com suplementação de $K$ (a) e resposta à adubação mineral e à aplicação de $10 \mathrm{tha}^{-1}+K+P(\mathrm{~b})$, aos 12,24 e 36 meses de idade $(8,20$ e 32 meses pósaplicação do biossólido). 


\section{CONCLUSÕES}

1) A Fertilidade do solo elevou-se gradualmente após a aplicação do biossólido. Houve elevação dos teores de matéria orgânica, de Pdisponivel e Ca trocável nas profundidades 0-5, 5-10 e 10-20 cm: e

2) O biossólido afetou positivamente a nutrição das plantas, gerando ganhos de produtividade superiores à obtida com adubação mineral. 


\section{REFERÊNCIAS BIBLIOGRÁFICAS}

ANDRADE, C.A. Nitratos e metais pesados no solo e em plantas de Eucalyptus grandis após aplicação de biossólido da ETE de Barueri. Piracicaba, 1999. 65p. Dissertação (Mestrado) - Escola Superior de Agricultura "Luiz de Queiroz", Universidade de São Paulo.

ANDREOLI, C.V.; BONNET, B.R.P.; LARA, A.I.; WOLTER, F.R. Proposição de plano de monitoramento da reciclagem agrícola do lodo de esgoto no Estado do Paraná. SANARE, v.7, n.7, p.76-84, 1997.

ASSOCIAÇÃO BRASILEIRA DE NORMAS TÉCNICAS. Fórum nacional de normatização: NBR 10004 resíduos sólidos. Rio de Janeiro, 1987. 63p.

AYUSO M.; PASCUAL, J.A.; GARCIA, C.; HERNÁNDEZ, T. Evaluation of urban wastes for agricultural use. Soil Science and Plant Nutrition, v.4, n.1, p.105-111, 1996.

BANERJEE, M.R.; BURTON, D.L.; DEPOE, S. Impact Of sewage sludge application on soil biological characteristics. Agriculture, Ecosystems and Environment, v.66, p.241-249, 1997.

BARROS, N.F.; NOVAIS, R.F. Eucalypt nutriotion and fertilizer regimes in Brazil. In: ATTIWILL, P.M.; ADAMS, M.A. (Ed.) Nutrition of eucalypt. Melbourne: CSIRO, 1996. cap.15, p.335-355. 
BARROS, N.F.; NOVAIS, R.F.; NEVES, J.C. L.; GOMES, J.M. Interpretação de análises químicas de solo para o crescimento de Eucalyptus spp. Revista Árvore, v.6, n.1, p.38-44, 1982.

BEKUNDA, M.A.; SMETHURST, P. J.; KHANNA, P.K.; WILLET, I.R. Effects of post-harvest residue management on labile soil phosphorus in a Pinus radiata plantation. Forest Ecology and Management, v.38, p.13-25, 1990.

BELLOTE, A.F.J.; FERREIRA, C.A. Nutrientes minerales y crescimiento de árboles abonados de Eucalyptus grandis en el Estado de São Paulo. Bosque, v.16, n.1, p.69-75, 1995.

BELLOTE, A.F.J.; SILVA, H.D. Técnicas de amostragem e avaliações nutricionais em plantios de Eucalyptus spp. In: GONÇALVES, J.L.M.; BENEDETTI, V. (Ed.) Nutrição e fertilização florestal. Piracicaba: IPEF, 2000. cap.4, p.105-133.

BERTON, R.S.; CAMARGO, O.A.; VALADARES, J.M.A.S. Absorção de nutrientes pelo milho em resposta à adição de lodo de esgoto a cinco solos paulistas. Revista Brasileira de Ciência do Solo, v.13, p.187-192, 1989.

BEVACQUA, R.F.; MELLANO, V.J. Cumulative effects of sludge compost on crop yields and soil properties. Communications in Soil Science and Plant Analysis, v.25, n. 3/4, p. 395 - 406, 1994.

CARDOSO, E.J.B.N; FORTES-NETO, P. Aplicabilidade do biossólido em plantações florestais: III. Alterações microbianas no solo. In: BETTIOL, W.; CAMARGO, O.A. Impacto ambiental do uso agrícola do lodo de esgoto. Jaguariúna: EMBRAPA Meio Ambiente, 2000. cap.10, p.197-202. 
CARMO, J.B. Impacto da aplicação de biossólido nas atividades microbianas do solo. Piracicaba, 2001. 105p. Dissertação (Mestrado) - Escola Superior de Agricultura "Luiz de Queiroz", Universidade de São Paulo.

CARVALHO, P.C.T.; BARRAL, M.F. Aplicação de lodo de esgoto como fertilizante. Fertilizantes, v.3, n.2, p.3-5, 1981.

COMPANHIA DE SANEAMENTO DO PARANÁ. Manual técnico para utilização agrícola do lodo de esgoto no Paraná. Curitiba: Sanepar, 1997. 96p.

COMPANHIA DE TECNOLOGIA DE SANEAMENTO AMBIENTAL Aplicação de biossólido de sistemas de tratamento biológico em áreas agrícolas: critérios para projeto e operação, São Paulo, 1999. 33p. (Manual Técnico, P. 4.230).

CHAVES, L.H.G.; LIBARDI, P.L. Lixiviação de $\mathrm{K}$ e Ca+Mg influenciada pelo pH. Revista Brasileira de Ciência do Solo, v.19, p.145-148, 1995.

COSTA, M.P. Efeito da matéria orgânica em alguns atributos do solo. Piracicaba, 1983. 137p. Dissertação (Mestrado) - Escola Superior de Agricultura "Luiz de Queiroz", Universidade de São Paulo.

DA ROS, C.O.; AITA. C.; CERETTA, C.A.; FRIES, M.R. Lodo de esgoto: efeito imediato no milheto e residual na associação aveia-ervilhaca. Revista Brasileira de Ciência do Solo, v.17, p.257-261, 1993.

DEFELIPO, B.V.; BRAGA, J.M. Influência da calagem e fontes de $K$ na absorção de $\mathrm{K}$ em latossolos de Minas Gerais. Revista Brasileira de Ciência do Solo, v.7, p.119-122, 1983. 
DURIEZ, M.M. Movimentação e lixiviação de Ca e K em resposta à calagem e adubação potássica em colunas de solos. Viçosa, 1994. 102p. Dissertação (M.S.) - Universidade Federal de Viçosa.

DUTCH, J.; WOLSTENHOLME, R. The effects of sewage sludge to a heathland site prior to planting with Sitka spruce. Forest Ecology and Management, v.66, n.1, p.151-163, 1994.

FERNANDES, F. Estabilização e higienização do biossólidos. In: BETTIOL, W.; CAMARGO, O.A. (Ed.) Impacto ambiental do uso agrícola do lodo de esgoto. Jaguariúna: EMBRAPA Meio Ambiente, 2000. cap. 3, p.45-67.

FOLLE, F.; SHUFORD, J.W.; TAYLOR, R.W.; MEHADI, A.A.; TADESSE, W. Effect of sludge treatment, heavy metal, phophate rate, and $\mathrm{pH}$ on soil phosporus. Communications in Soil Science and Plant Analysis, v.26, n.9/10, p. 1369-1381, 1995.

FORTES NETO, P. Degradação de biossólido incorporado ao solo avaliado através de medidas microbiológicas. Piracicaba, 2000. 113p. Tese (Doutorado) - Escola Superior de Agricultura "Luiz de Queiroz", Universidade de São Paulo.

FURTINI-NETO, A.E.; VALE, F.R.; MUNIZ, J.A.; GUEDES, G.A.A. Efeito do enxofre no crescimento de cinco espécies de eucalipto. Revista Árvore, v.12, n.1, p.1-11, 1988.

GONÇALVES, J.L.M.; BARROS, N.F. Improvement of site productivity for short-rotation plantations in Brazil. Bosque, v.20, n.1, p.89-106, 1999. 
GONÇALVES, J.L.M.; RAIJ, B. van; GONÇALVES, J.C. Florestais. In: RAIJ, B. van; CANTARELLA, H.; QUAGGIO, J.A.; FURLANI, A.M.C. (Ed.) Recomendações de adubação e calagem para o estado de São Paulo. Campinas: Instituto Agronômico \& Fundação IAC, 1996. cap.23. p.247-259.

GONÇALVES, J.L.M.; BARROS, N.F.; NEVES, J.C.L.; NOVAIS, R.F. Níveis críticos de fósforo no solo e na parte aérea de eucalipto na presença e ausência de calagem. Revista Árvore, v.10, n.1, p.91-104, 1986.

GONÇALVES, J.L.M.; BARROS, N.F.; NAMBIAR, E.K.S.; NOVAIS, R.F. Soil and stand management for short-rotation plantations. In: NAMBIAR, S.; BROWN, A. (Ed.). Management of soil, nutrients and water in tropical plantation forests. Camberra: ACIAR; CSIRO; CIFOR, 1997. cap.11, p.379-418.

GONÇALVES, J.L.M.; STAPE, J.L.; BENEDETTI, V.; FESSEL, V.A.G.; GAVA, J.L. Reflexos do cultivo mínimo e intensidade do solo em sua fertilidade e na nutrição das árvores. In: GONÇALVES, J.L.M.; BENEDETTI, V. (Ed.) Nutrição e fertilização florestal. Piracicaba: IPEF, 2000. cap.1, p.1-57.

GUEDES, M.C. Efeito do lodo de esgoto (biossólido) sobre a nutrição, ciclagem de nutrientes e crescimento de sub-bosque, em plantação de eucalipto. Piracicaba, 2000. 74p. Dissertação (Mestrado) - Escola Superior de Agricultura "Luiz de Queiroz", Universidade de São Paulo.

HENRY, C.L.; COLE, D.W.; HARRISON, R.B. Use of municipal sludge to restore and improve site productivity in forestry: the pack forest sludge research program. Forest Ecology and Management, v.66, p.137-149, 1994. 
JORGE, J.A.; CAMARGO, O.A.; VALADARES, J.M.A.S. Condições físicas de um latossolo vermelho-escuro quatro anos após aplicação de lodo de esgoto e calcáreo. Revista Brasileira de Ciência do Solo, v.15, p.237-240, 1991.

KIEHL, E. J. Fertilizantes orgânicos. Piracicaba: Agronômica "Ceres", 1985. cap.2, p.26-84: Efeitos da matéria orgânica sobre as propriedades do solo.

LAMBAIS, M.R.; SOUZA, A.G. Impacto de biossólidos nas comunidades microbianas dos solos. In: BETTIOL, W.; CAMARGO, O.A. (Ed.) Impacto ambiental do uso agrícola do lodo de esgoto. Jaguariúna: EMBRAPA Meio Ambiente, 2000. cap.17, p.269-279.

LINDSAY, W.L.; NORVELL, W.A. Development of a DTPA soil test for zinc, iron, manganese and copper. Soil Science Society of America Journal, v.42, p.421-428, 1978.

MARIA, I.C. Influência da matéria orgânica sobre o calcário aplicado sobre o solo. Piracicaba, 1986. 90p. Dissertação (Mestrado) - Escola Superior de Agricultura "Luiz de Queiroz", Universidade de São Paulo.

McDONALD, M.A.; HAWKINS, B.J.; PRESCOTT, C.E.; KIMMINS, J.P. Growth and foliar nutrition of wester red cedar fertilized with sewage sludge, pulp sludge, fish silage, and wood ash on northern Vancouver Island. Canadian Journal of Forest Research, v.24, p.297-301, 1994.

McNAB, W.H.; BERRY, C.R. Distribution of aboveground biomass in three pine species planted on a devasted site amended with sewage sludge or inorganic fertilizer. Forest Science, v.31, n.2, p.373-382, 1985. 
MELO, W.J.; MARQUES, M.O. Potencial do lodo de esgoto como fonte de nutrientes para as plantas. In: BETTIOL, W.; CAMARGO, O.A. Impacto ambiental do uso agrícola do lodo de esgoto. Jaguariúna: EMBRAPA Meio Ambiente, 2000. cap.5, p.109-141.

MELO, W.J.; MARQUES, M.O.; SANTIAGO, G.; CHELLI, R.A.; LEITE, S.A.S. Efeito de doses crescentes de lodo de esgoto sobre frações da matéria orgânica e CTC de um latossolo cultivado com cana-de-açucar, Revista Brasileira de Ciência do Solo, v.18, p.449-455, 1994.

MIYAZAWA, M.; CHIERICE, G.O.; PAVAN, M.A. Amenização da toxicidade de alumínio às raizes do trigo pela complexação com ácidos orgânicos. Revista Brasileira de Ciência do Solo, v.16, p.209-215, 1992.

NOVAIS, R.F.; JOT SMYTH, T. Fósforo em solo e planta em condições tropicais. Viçosa: Universidade Federal de Viçosa, Departamento de Solos, 1999. 300p.

OLIVEIRA, F.C.; MARQUES, M.O.; BELLINGIERI, P.A. ; PERECIN, D. Lodo de esgoto como fonte de macronutrientes para a cultura do sorgo granífero. Scientia Agricola, v.52, n.2, p.360-367, 1995.

PHILLIPS, R.; FISHER, J.T.; MEXAL, J.G. Fuelwood production utilizing Pinus eldarica and sewage sludge fertilizer. Forest Ecology and Management, v.16, p.95-102, 1986. 
POLGLASE, P.J.; MYERS, B.J. Tree plantations for recycling effluent and biosolids in Australia. In: ELBRIDGE, K.G.; CROWE, M.P.; OLD, K.M. (Ed.) Environment management: the role of eucalypts and other fast growing species. Melbourne: CSIRO, 1995. p.100-109.

PRIMAVESI, A. Manejo ecológico do solo: a agricultura em regiões tropicais. São Paulo: Nobel, 1987. cap.8, p.258: A adubação e a nutrição vegetal.

RAIJ, B. van; ANDRADE, J.C.; CANTARELLA, H. Análise química para avaliação da fertilidade de solos tropicais. Campinas: Instituto Agronômico, 2001. 285p.

RAIJ, B. van; QUAGGIO, J.A.; CANTARELLA, H.; FERREIRA, M.E.; LOPES, A.S.; BATAGLIA, O.C. Análise química do solo para fins de fertilidade. Campinas: Fundação Cargill, 1987. 170p.

ROCHA, M.T. Utilização de lodo de esgoto na agricultura: um estudo de caso par as bacias hidrográficas dos rios Piracicaba, Capivarí e Jundiaí. Piracicaba, 1998. 140p. Dissertação (Mestrado) - Escola Superior de Agricultura 'Luíz de Queiroz', Universidade de São Paulo.

ROSATO, F.M. Efeito da calagem e da matéria orgânica sobre a acidez de cinco solos do município de Piracicaba. Piracicaba, 1978. 43p. Dissertação (Mestrado) - Escola Superior de Agricultura "Luiz de Queiroz", Universidade de São Paulo.

SANTOS, H.F. Aplicação do lodo de Estações de Tratamento de Esgoto em solos agrícolas. Revista DAE, v.39, n.122, p.31-48, 1979. 
SANTOS, H.F.; GUIMARÃES, M.O.; GIUSTI, E.A. Uso do lodo de ETEs em reflorestamentos. In: ENCONTRO TÉCNICO DA ASSOCIAÇÃO DE ENGENHEIROS DA SABESP, 8., São Paulo, 1997. Anais. São Paulo: SANEAS, 1997. p.1-23.

SARRUGE, J.R. ; HAAG, H.P. Análise química em plantas. Piracicaba, ESALQ, 1974. 56p.

SOCIEDADE BRASILEIRA DE SILVICULTURA. Área plantada com pinus e eucaliptos no Brasil - 2001. http://www.sbs.org.br/secure/estatisticas.htm (08 ago. 2002).

SILVA, F.C. Uso agronômico de lodo de esgoto: efeitos em fertilidade do solo e qualidade de cana-de-açucar. Piracicaba, 1995. 154p. Tese (Doutorado) Escola Superior de Agricultura "Luiz de Queiroz", Universidade de São Paulo.

SILVEIRA, R. L.V.A.; HIGASHI, E.N.; GONÇALVES, A.N.; MOREIRA, A. Avaliação do estado nutricional do Eucalyptus: diagnose visual, foliar e suas interpretações. In: GONÇALVES, J.L.M.; BENEDETTI, V. Nutrição e fertilização florestal. Piracicaba: IPEF, 2000. cap.3, p.79-104.

SKOUSEN J.; KLINGER, C. Sewage sludge land application progam in West Virginia. Journal of Soil and Water Conservation, v.48, n.2, p.145-151, 1998.

SORT, X.; ALCAÑIZ, J.M. Modification of soil porosity after application of sewage sludge. Soil \& Tillage Research, v.49, p.337-345, 1999. 
UCHÔA, S.C.P. Dinâmica de formas lábeis e não lábeis de enxofre no solo. Viçosa, 1999. 105p. Tese (Doutorado) - Universidade Federal de Viçosa.

ESTADOS UNIDOS. Agency Protection Environment. Standards for the use or disposal of sewage sludge: 40 CFR parts 257, 403 and 503 . Federal Register, v.58, n.32, p.9248-9415, 1993.

VAZ, L.M.S. Crescimento inicial, fertilidade do solo e nutrição de um povoamento de Eucalyptus grandis fertilizado com biossólido. Piracicaba, 2000. 41p. Dissertação (Mestrado) - Escola Superior de Agricultura "Luiz de Queiroz", Universidade de São Paulo.

VAZ, L.M.S.; GONÇALVES, J.L.M. Uso de biossólidos em povoamento de Eucalyptus grandis: Efeito em atributos químicos do solo, no crescimento e na absorção de nutrientes. Revista Brasileira de Ciência do Solo, 2002 /No prelo/.

WANG, M. Land application of sewage sludge in China. The Science of the Total Environment, v.197, p.149-160, 1997.

WEETMAN, G.F.; MCDONALD, M.A.; PRESCOTT, C.E; KIMMINS, J.P. Responses of western hemlock, pacific silver fir, and western red cedar plantations on northern Vancouver Island to applications of sewadge sludge and inorganic fertilizer. Canadian Journal of Forest Research, v.23, p.1815-1820, 1993. 